\title{
Monumental Architecture, Settlement Landscape, and Climate Change at El Infiernito, Colombia
}

\author{
Michael P. Smyth \\ The Foundation for Americas Research, Inc., USA.
}

How to cite this paper: Michael P. Smyth. (2021) Monumental Architecture, Settlement Landscape, and Climate Change at El Infiernito, Colombia. Journal of Humanities, Arts and Social Science, 5(1), 89-110. DOI: $10.26855 /$ jhass.2021.01.010

Received: February 12, 2021

Accepted: March 18, 2021

Published: April 14, 2021

"Corresponding author: Michael P. Smyth, The Foundation for Americas Research, Inc., USA.

Email: mpsmyth@netzero.net

\begin{abstract}
The ancient Muisca in the Valley of Leiva of the Eastern Andean Cordillera were monument buildings strongly influenced by climate change. Research at El Infiernito, the Stonehenge of Colombia, examined socio-environmental contexts related to the impacts of drought, flooding, and erosion vital to the development of past chiefdom societies. Chiefly elites responded to adverse water-related conditions by engineering a hydraulic landscape but also modified their built environment employing stone architecture and stone monuments that embodied religious and celestial cosmology. Investigations at a rare stone building and the discovery of nearby human burials begin to show evidence for a chiefly compound at El Infiernito. Reconnaissance nearby also located new irrigation works and astronomical-related monuments that appears to correspond to a quintuple planetary grouping visible in $710 \mathrm{AD}$. These data show that elites employed both tangible and intangible responses to overcome limitations posed by the natural and cultural environments.
\end{abstract}

Keywords

Architecture, Archaeology, Hydraulics, Climate change, Cosmology

\section{Introduction}

In the Leiva Valley of the Eastern Andean Highlands, the ancient Muisca constructed sophisticated stone monuments tied to celestial cosmology and rites of fertility. Climate change was also a factor in the development of their complex society. Research focusing on the archaeological site of El Infiernito, the "Stonehenge" of Colombia, provides socio-environmental contexts including architecture and settlement landscapes to begin reconstructing the roles of drought cycles, flooding events, and landscape erosion in the formation of Colombian chiefdoms. While most archaeological studies in the Eastern Andes emphasize social history and ideological causation, this work focuses on the links between environmental systems and socio-cultural processes. The settlement landscape and key water ways were subject to major erosion episodes related to prolonged regional drought and extreme flooding that greatly impacted irrigation farming for past ranked societies, kinship-based social groups with unequal access to status positions and prestige. Chiefly elites began constructing stone buildings in segregated compounds from where they attempted to mitigate unpredictable water supplies by engineering a hydraulic landscape but also employing religious cosmology related to celestial events embodied in the stone monuments of a solar observatory. Studying the socio-ecological dynamics of coupled human and natural systems (human ecodynamics), climate change and other related phenomena provide insights into how such forces interacted to promote culture evolution.

This paper discusses the context of a unique stone building located on private lands near the Archaeological Park of Monquira (El Infiernito). In 2010, all surface stones related to this structure were removed and relocated. However, the landowners extended an invitation in 2015-2016 to investigate the original site by methods of controlled exca- 
vation to salvage any remaining evidence for this rare stone building of the ancient Muisca. Also, by a nearby stream channel, human burials were exposed by recent landscaping revealing a mortuary context that appears to border a chiefly compound. Furthermore, reconnaissance survey around El Infiernito recorded new data related to irrigation and potential archaeo-astronomical monuments that place the site in broader regional context for Muisca subsistence and cosmology.

\section{Background}

Located $120 \mathrm{~km}$ NE of Bogota (Figure 1a), the Leiva valley was populated with Muisca chiefdoms along river floodplains surrounded by upland mountains reaching 3,500 m (Langebaek, 1995; Langebaek, 2001). Climate classification is tierra frio except for desert páramo above 3,500 m with a dual rainy season occurring from March to June and again in October through November separated by intervening dry seasons; evidence for past valley erosion is intense. Overall, the river floodplain around El Infiernito is semiarid averaging about 1,000 mm per year though evapotranspiration is nearly as high with considerable annual precipitation variation throughout the valley based upon elevation. July is the coldest month when frosts are possible especially at higher altitudes. In addition, the major uplands rivers such as the Rio Moniquirá and smaller ones like the Rio Leyva flow near Muisca settlements in the valley, including the 16th century chiefdom of Zaquencipá at El Infiernito (Falchetti, 1975; Salamanca, 2000; Henderson \& Ostler, 2005).

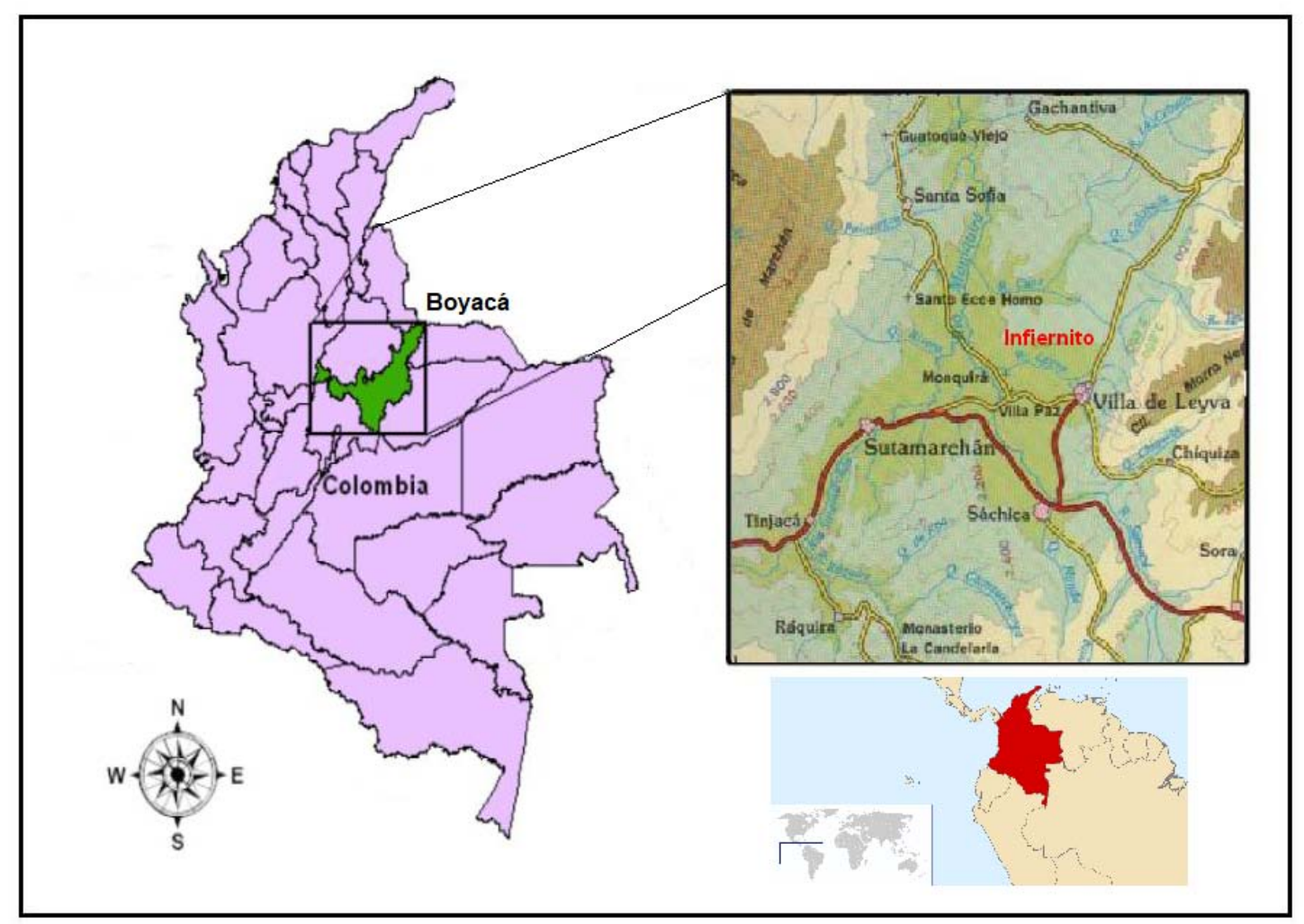

Figure 1a. Map of Colombia, South America and the Department of Boyacá with an inset showing the locations of Valley of Leiva, Villa de Leyva, and the site of El Infiernito as well as other towns/sites throughout valley.

El Infiernito (2,075 m elv.), $6 \mathrm{~km} \mathrm{NW}$ of the town of Villa de Leyva (Figure 1b), is an archaeological park famous for its stone monuments (menhires). Highlighted by an E-W double row of worked columns forming a rectilinear structure which served, allegedly, for astronomical-meteorological observations between 700 and 1200 AD (Langebaek, 2001, p. 28). Recent survey work has documented the presence of a Herrera phase (700-1000 AD) small-scale farming community when some of the first monoliths may have been erected (Botiva, 1989; Langebaek, 1995). Subsequent Early Muisca communities (1000-1200 AD) are credited with constructing the observatory who concentrated in larger settlements that saw the formation of chiefdom leadership organization. Late Muisca 
(1200-1600 AD) occupations were progressively larger (Salge, 2007) and more complex. In some highland regions, Muisca chiefdoms were becoming more centralized resulting in increased population distribution with nucleated settlements supported by intensified agriculture, interregional trade (salt, ceramics, gold, and textiles) organized warfare, mummification, craft specialization (including gold working, emerald mining, and textile weaving). At Tunja and Bogotá before the Spanish Conquest, for example, the Muisca were controlled by powerful paramount chiefs who were becoming politically stratified and beginning to absorb regional communities.

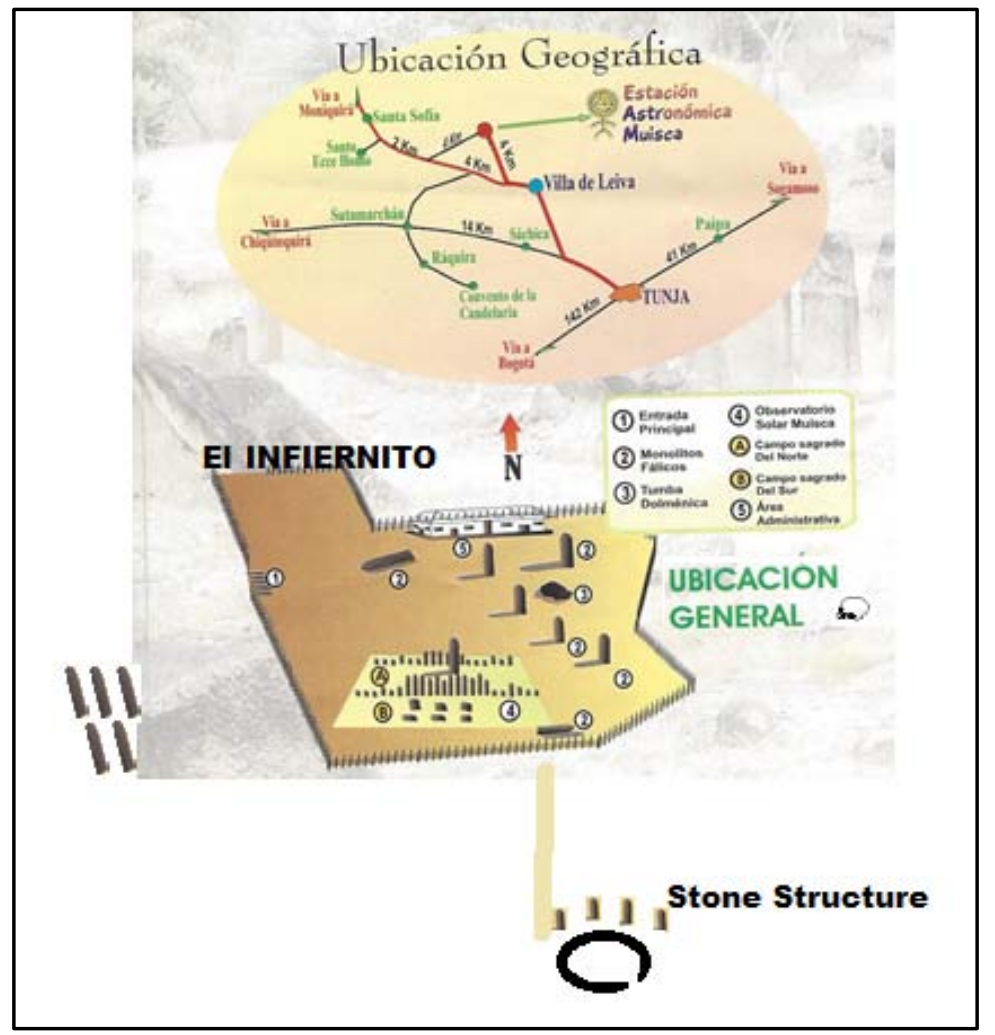

Figure 1b. Map of the Valley of Leyva, the archaeological park of El Infiernito, and the oval stone structure and associated monoliths investigated in 2015. Five megaliths (left) and burials (skull) are west and east of the park, respectively.

The stone monoliths at the Infiernito have been the subject of much attention beginning with the first Spanish missionaries who maligned them as works of the devil and claimed associations with controversial Muisca rituals and orgiastic ceremonies, and perhaps most significantly, the native resistance to Spanish Catholicism (Simón, 1981). Among the first archaeological expeditions detailing the various stone columns occurred in 1846 (Zerda, 1972). Shortly thereafter, Joaquin Acosta wrote a new appraisal of the site dismissing prior claims of any 'lost race' responsible for erecting the monoliths (Acosta, 1850), while others argued correctly that chibcha-speaking (Muisca) native peoples were the actual builders (Ancízar, 1983). As archaeology became a formal discipline in Colombia, studies began to focus on classification of the stones as well as associated artifacts and human remains (Restrepo, 1972; Sáenz, 1968; Triana, 1972), though their excavations and analyses were not congruent with modern standards.

The first modern study of the observatory was by Eliécer Silva Celis (1981) who excavated the so-called Campos Sagrados del Norte y Sur (Figures 2a and 2b). At the former, he uncovered a row of 26 carved cylindrical pillars, or narrow columns, equally spaced following the meridian-20 additional columns were reconstructed. A parallel southern row of some 54 columns was completely restored (Silva, 1983). Four meters south, the Campo Sagrado de Sur is composed of 2 rows of four large ovoid columns (Moncada, 1979) whose true function remains uncertain though the spacing of columns and play of light-and-shadow following the movement of the sun are claimed to be astronomical (Silva, 1981, p. 3). Unfortunately, few statistical and graphical presentations were published reporting critical context and association information for the excavations. Three published radiocarbon assays $(2180 \pm 140$, $2490 \pm 195,2880 \pm 95$ BP uncorrected) lacked detailed descriptions of the contexts of association for carbon samples (Silva, 1981, p. 13) and produced controversial dates reported by El Instituto de Asuntos Nucleares, which has a reputation for inaccurate results (Langebaek, 2001, p. 28). 


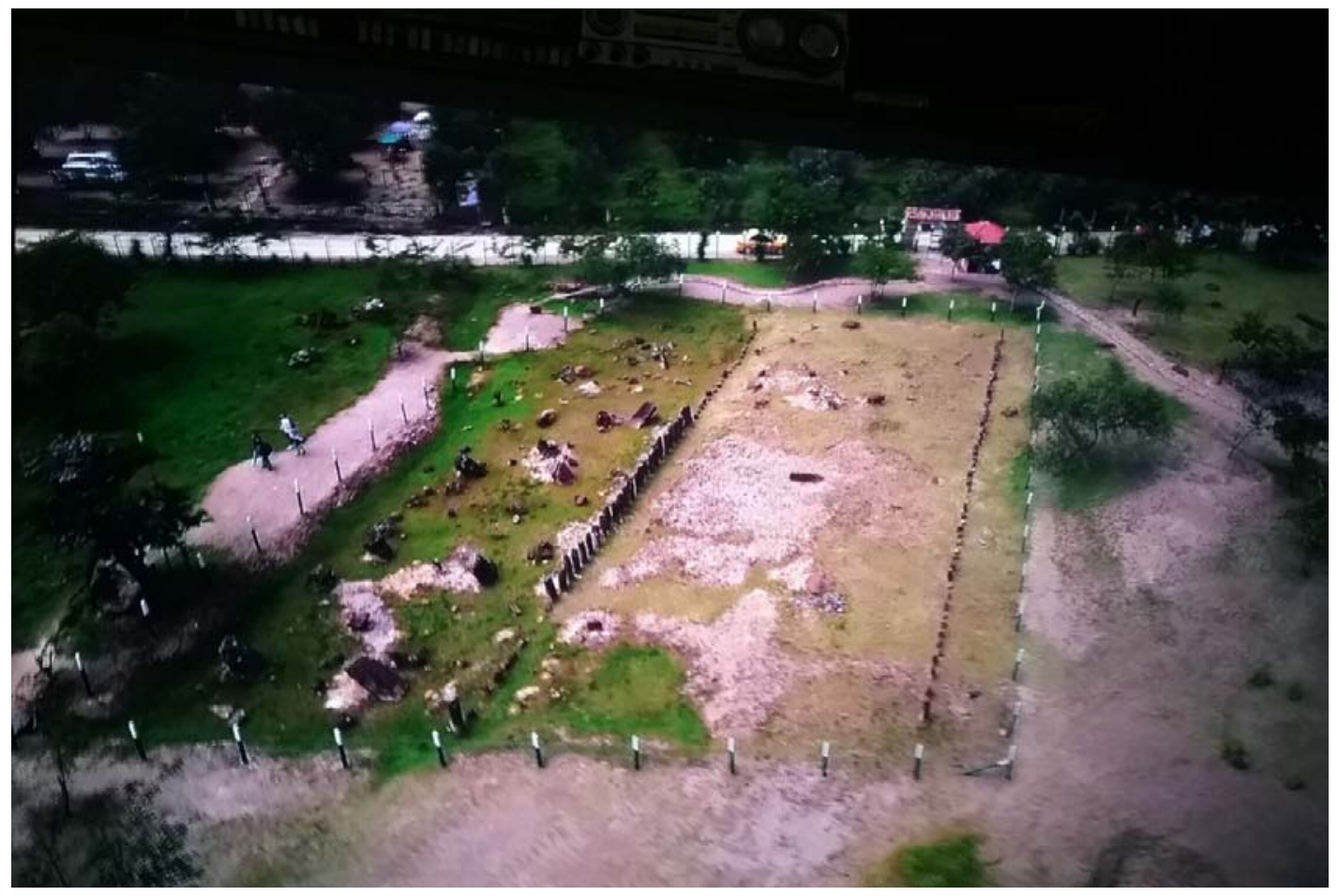

Figure 2a. Air photo looking west showing the astronomical observatory (North and South Zones) at Infiernito. The reported5-m tall center column between the stone rows has been missing for some time.

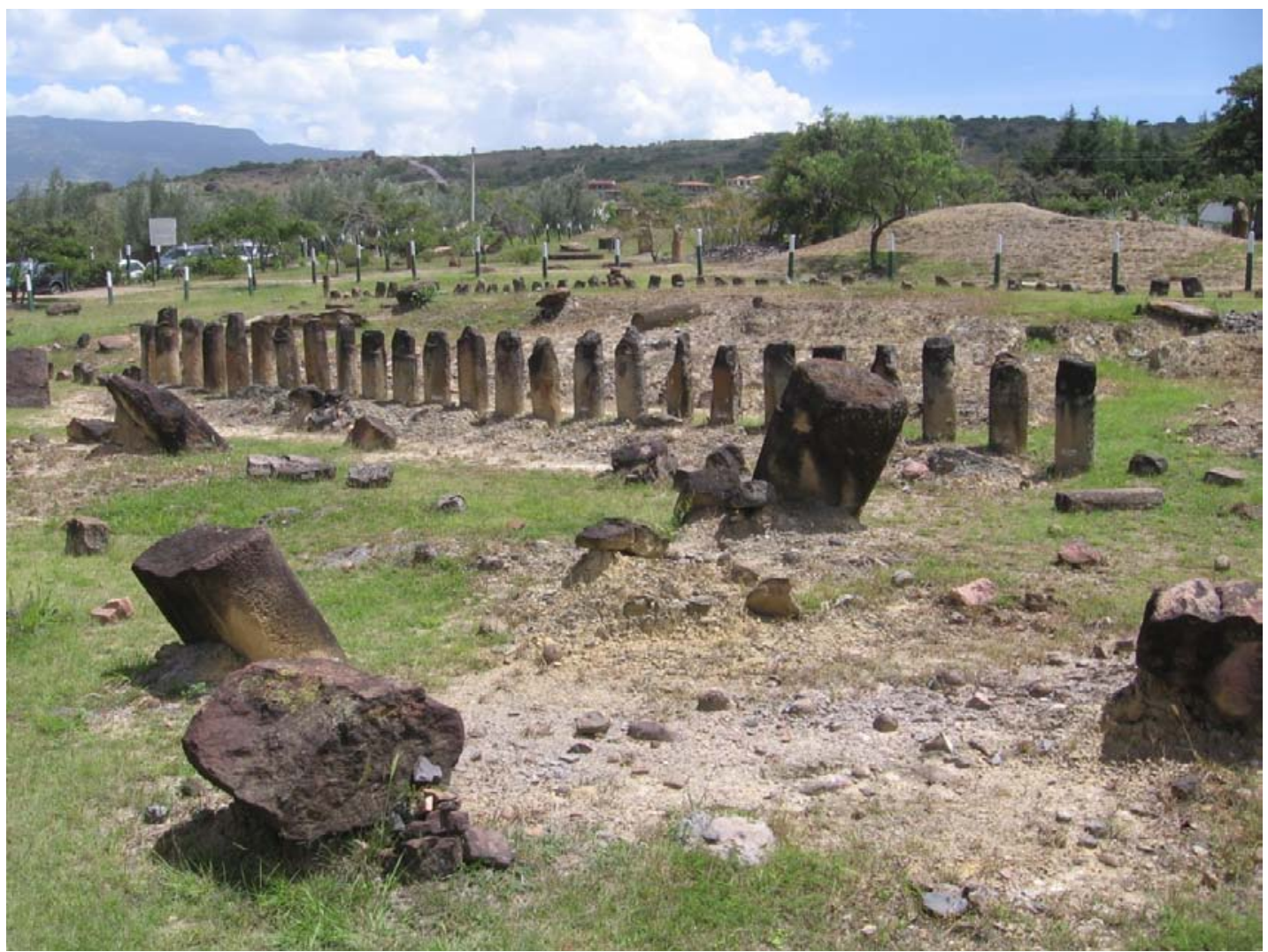

Figure 2b. El Infiernito Observatory looking northwest showing two rows of stone columns and various monoliths many reconstructed by Eliécer Silva Celis. The Loma la Cabrera is seen in the background. 
Two parallel rows of columns on the vernal equinox have a true (north) azimuth of $91^{\circ}$ pointing east towards the Cerro Morro Negro (Morales, 2009). The columns do not align with the Laguna de Iguaque on the equinox as previously claimed (cf. Silva, 1981; Morales, 2009; Reichel-Dolmatoff, 1982). Importantly, recent work shows a true diagonal azimuth of approximately $113^{\circ}$ measured from the westernmost column of the north row, passing through the alleged center column, continuing to the easternmost column of the south row, and ultimately aligns within one degree of the true helio-elliptical rising of the Winter Solstice (Smyth, 2017, p. 23, pp. 32-33). This significant alignment also corresponds to mountain fissures, stream channels of the Quebrada San Agustín, and a terrace platform situated behind Villa de Leyva and the nascent waters of the Rio Leyva. These alignments suggest that El Infiernito was a solar observatory focused on water and human and agricultural fertility, and not just a calendrical monument. The spatial connection between the water mountain and a terrace platform as well as eight stone portrait statues depicting symbols of fertility reportedly found nearby support the identification of a water temple (Smyth, 2017).

On the east side of the park are dozens of upright monoliths standing up to $4.5 \mathrm{~m}$ tall interpreted as phallus stones surrounding a rectangular dolomite (Dolménica) tomb constructed of slab boulders (Figures3a and 3b) that allegedly contained the remains of high status interments (Silva,1983). El Infiernito was clearly the center for a large chiefdom by the 12th century AD if not earlier. The astronomical and phallus cult interpretations of the various monuments remain perplexing, however, because so little is known about the surrounding community. A recent interpretation describing El Infiernito as a moiety (dual social groups) composed of ring-shaped Eastern (the astronomical observatory) and Western Sectors each with open plazas surrounded by residential settlement (Langebeak, 2013) is difficult to assess because of a lack of available published sampling data documenting a ring-shaped Western Sector. In fact, Manuel Salge's (2007, pp. 53-56) shovel testing survey in the vicinity appears to contradict the moiety model showing significant occupation in this area with no clear evidence of any open plaza. Our reconnaissance here observed surface artifacts, huge stone monoliths, and stream channels and/or possible canal features consistent with other site areas along the Rio Leyva floodplain suggesting past irrigation agriculture (Smyth et al., 2016). In addition, low artifact density interpreted as an open plaza could be the result of deeply buried settlement deposits from past flooding events along the river floodplain as documented by sediment trenching nearby (see below).

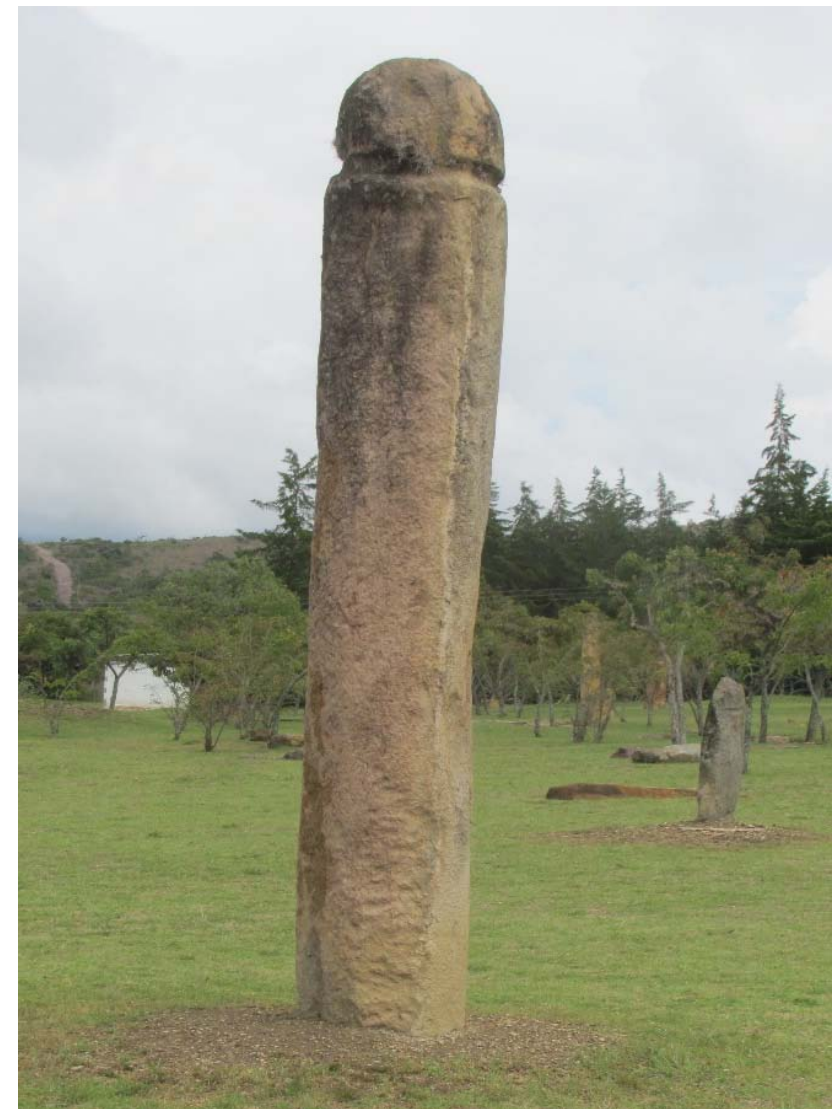

Figure 3a. A tall upright dolomite column of the eastern zone at Infiernito interpreted as a phallic monument. 


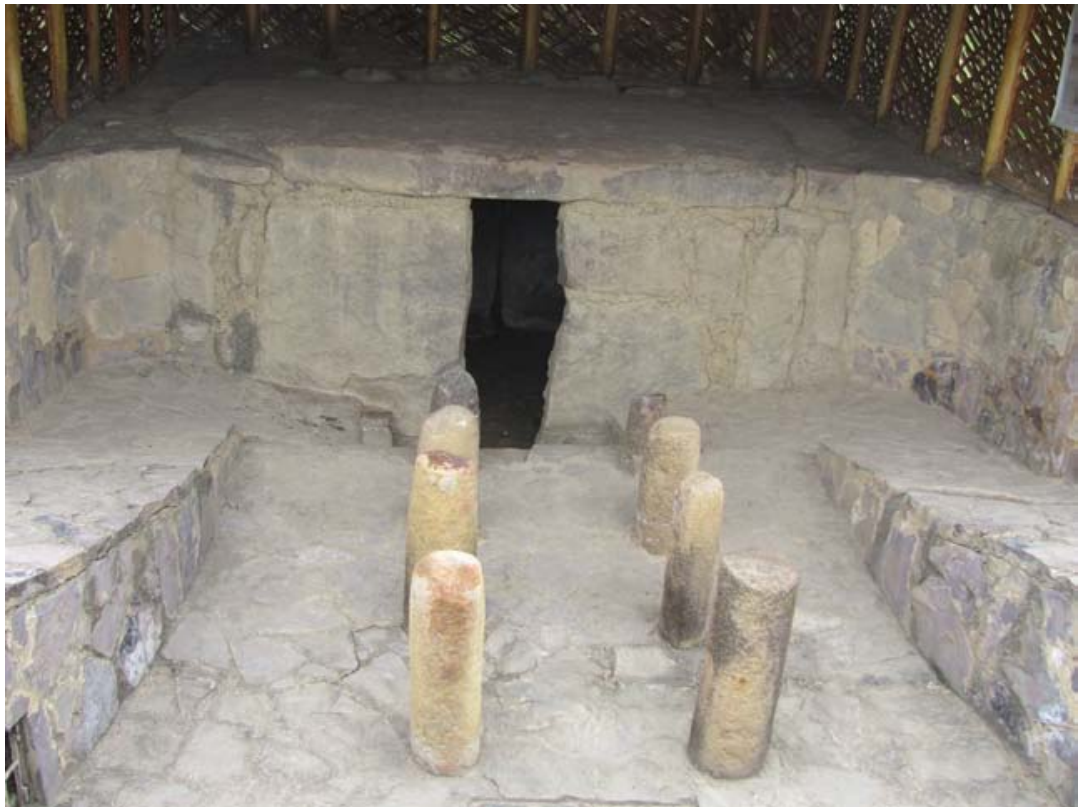

Figure 3b. The Dolménica tomb looking north shows eight columns aligned with the entry to a slab stone subterranean chamber where human remains were found. These columns also align with a raised walkway (camillón) to the south by the Stone Structure. The flagstone pavement in the foreground and masonry on the peripheries are modern additions.

\section{El Infiernito Research}

\section{Stone Structure 2015}

Salvage operations began at the original site of a stone structure to recover potential contextual information related to the building's monolithic stones now piled $25 \mathrm{~m}$ north (Figure 4). At the site context, tractor plowing for farming and the construction of utility infrastructure since stonework relocation exposed potential subsurface deposits. A goal was to establish the function and spatial context of a stone building and associated features near the monumental solar observatory outside the grounds of the archaeological park.

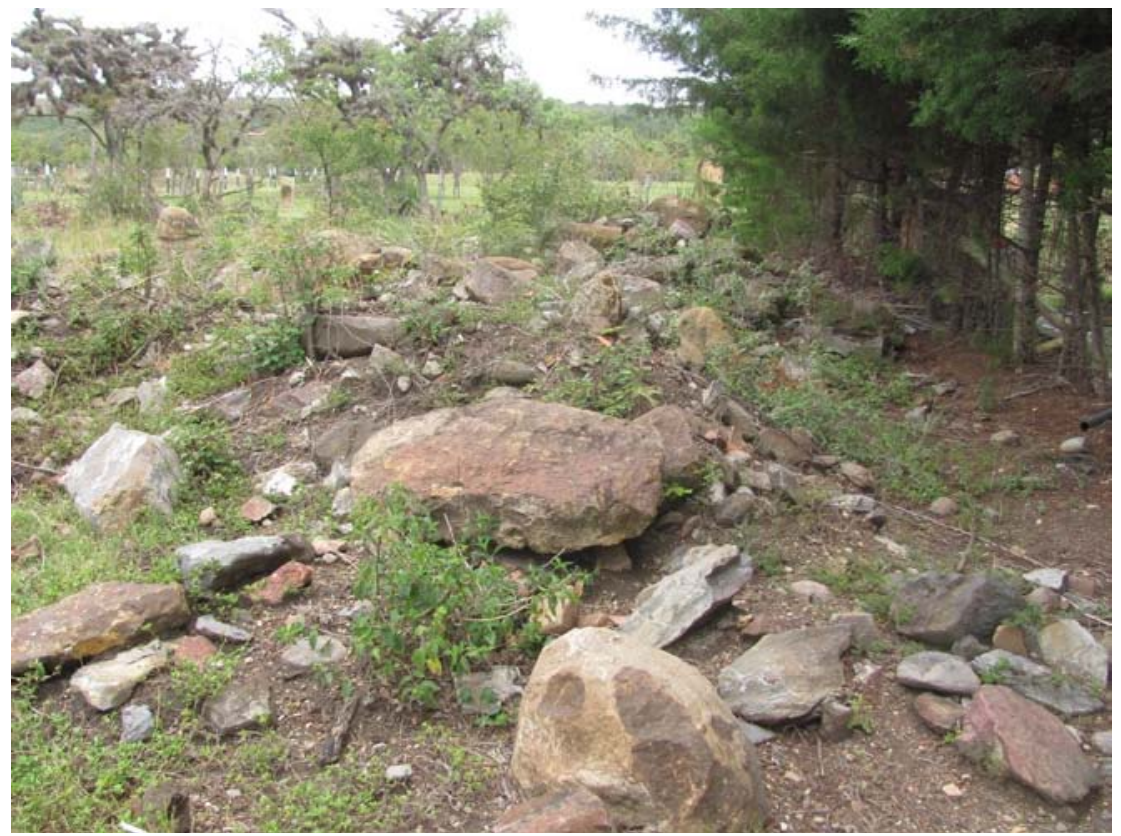

Figure 4. A stone pile of the relocated remains of the stone structure between the original building site (25 $\mathrm{m}$ south) and the Dolménica tomb. Note the phallic columns and wall slabs in the foreground, background, and structural debris throughout. 
Employing a $10 \mathrm{~m}$ baseline for spatial control, 2 x $2 \mathrm{~m}$ units revealed subsurface deposits including some that were already exposed. Tractor plowing of the top $20 \mathrm{~cm}$ produced highly mixed contexts but immediately below a soil horizon was relatively undisturbed. Operation 1 was placed in the structure's SE zone where landowners claimed there was an entryway. A tamped earthen floor and two circular molds for upright posts once supported a perishable roof; features that clearly suggest a building with rounded corners. On-floor impressions caused by the weight of two large jamb stones confirmed informant accounts of an entryway. Horizontal exposures following the floor north located additional postholes and numerous artifact concentrations including offerings of painted ceramic sherds, lithics, and deer bone/teeth (Figures 5 and 6). Deer fauna, decorated pottery, and other material wealth are often seen as indicators of elite status among Colombian highland chiefdoms (Boada, 2007). Importantly, a stone masonry base in situ approximately $1 \mathrm{~m}$ thick running E-W also yielded additional posthole features for a chiefly building. Though the wall base was taller in the past, undoubtedly reduced when the large stone slabs were removed, adjacent floor impressions suggest carved columnar monoliths (phallus stones) outside (north) the wall consistent with informant interviews (Figure 7). The wall base is faced with stones on a mud concrete hearting connected to corners that appear rounded, as indicated by the posthole configuration, giving this roofed structure an uncharacteristic oval or apsidal shape; most known Muisca buildings were round (Boada, 1998; Boada, 2000; Kruschek, 2003). It also appears that some upright posts were anchored into the wall base supporting large upright slabs for a superstructure composed of perishable upper walls and thatched roof. Further probes revealed additional postholes on the W, worked stone blocks on the NW, and three earthen subfloors on the south suggesting an initial Herrera phase occupation (Smyth et al., 2016). Based on ceramic diagnostics associated with packed earthen floors, the main structure appears to have been constructed sometime in the Early Muisca period with continued occupation into Late Muisca times.

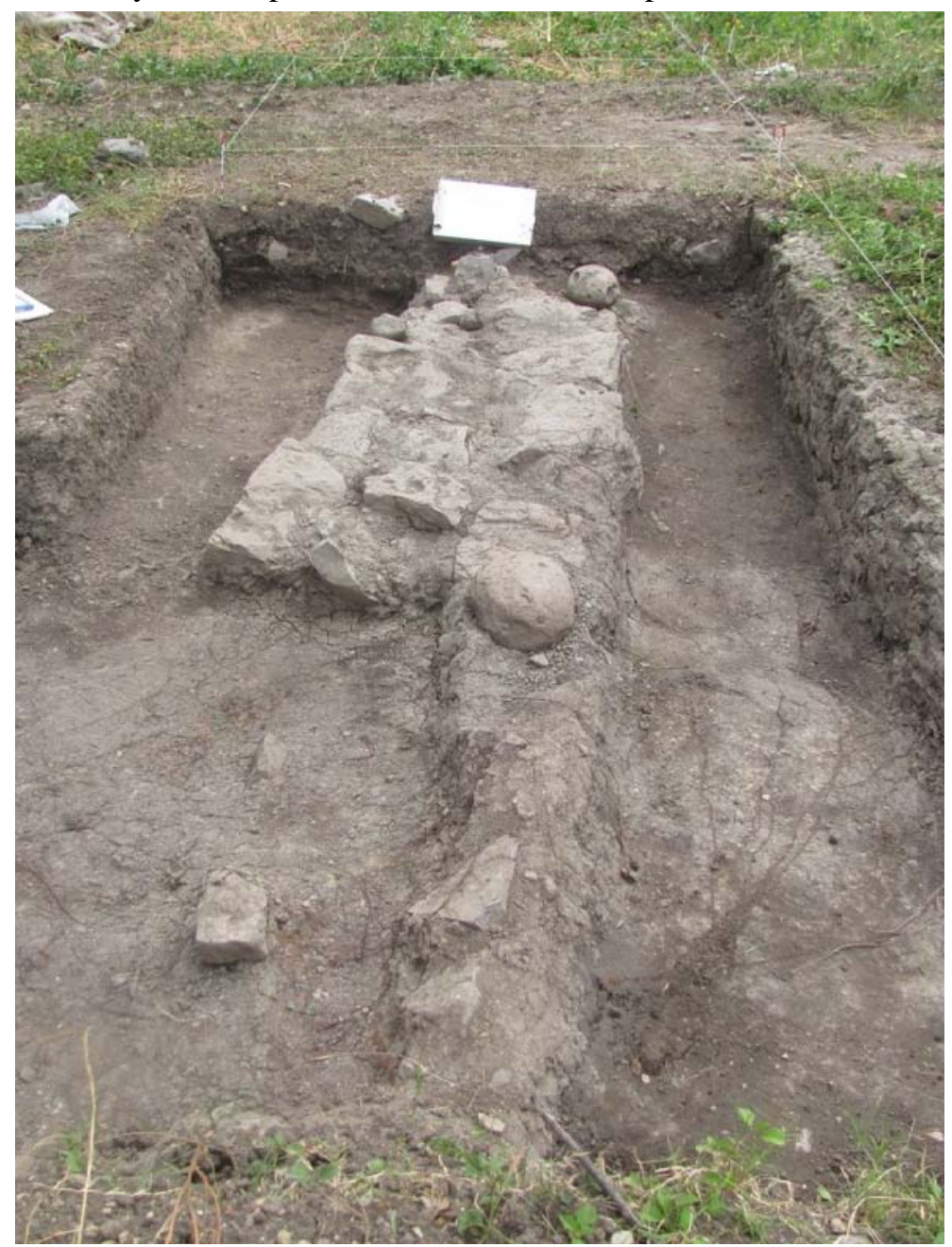

Figure 5. Operations 3 and 4 looking west showing an in situ north segment of a masonry wall base at the original building context that survived backhoe damage during stone removal in 2010. 


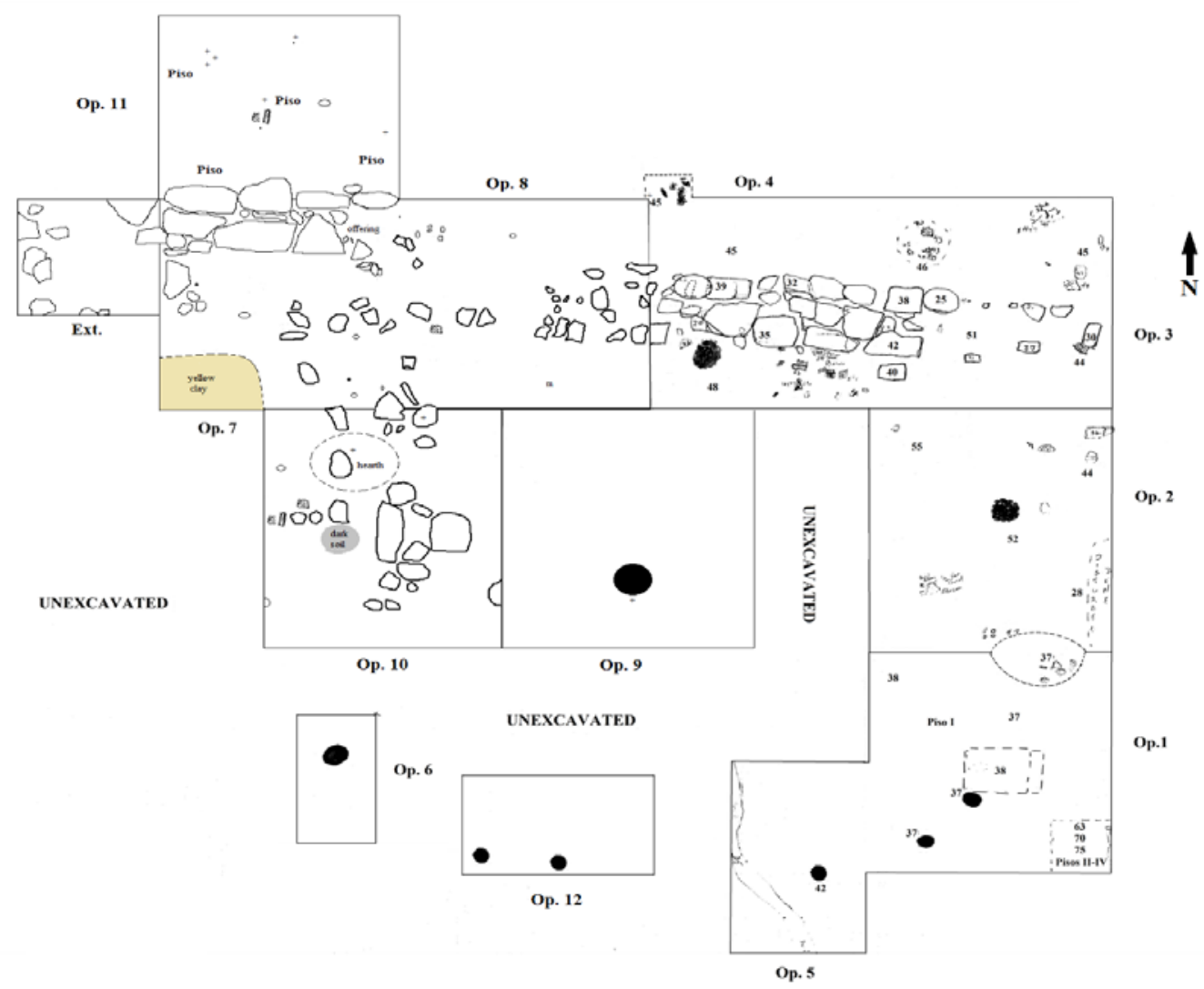

Figure 6. Plan map of the Stone Structure building context and locations of all operations (Ops.) showing stone features including wall base segments and alignments, packed earther floors (pisos) and posthole configuration. Most units are 2 x 2 m.

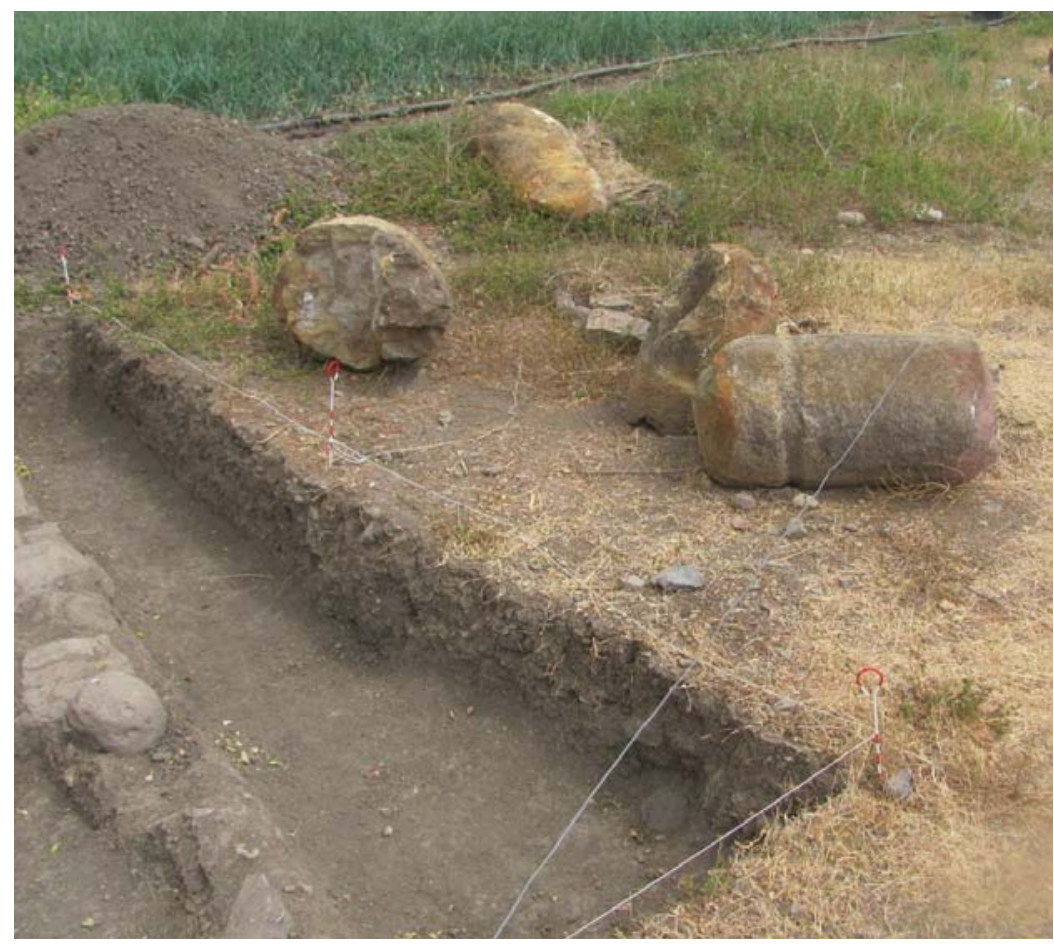

Figure 7. Four short phallic columns with relatively flat bases after relocation to their original locations outside the north wall base for the Stone Structure. 


\section{Human Remains}

Fieldwork paused in July of 2015 when all units were covered and secured. On a brief visit in November, human bone was reported on private land outside the archaeological park. Landowners again invited me to investigate and salvage any potential information. Upon inspection, I confirmed ancient human bone (Burial 1). Chaining pins were set out to demarcate an area of $1 \mathrm{~m}^{2}$ for exposure and pedestaling (Figure 8). A concentration of long bone, two small premolars, and pieces of cranium near the surface clearly indicate a pre-adolescent individual. While the top portion of the cranium was sheared off presumably by recent tractor activity, the rest of the burial was below surface in a seated position and relatively complete, though portions of the axial skeleton was broken or crushed.

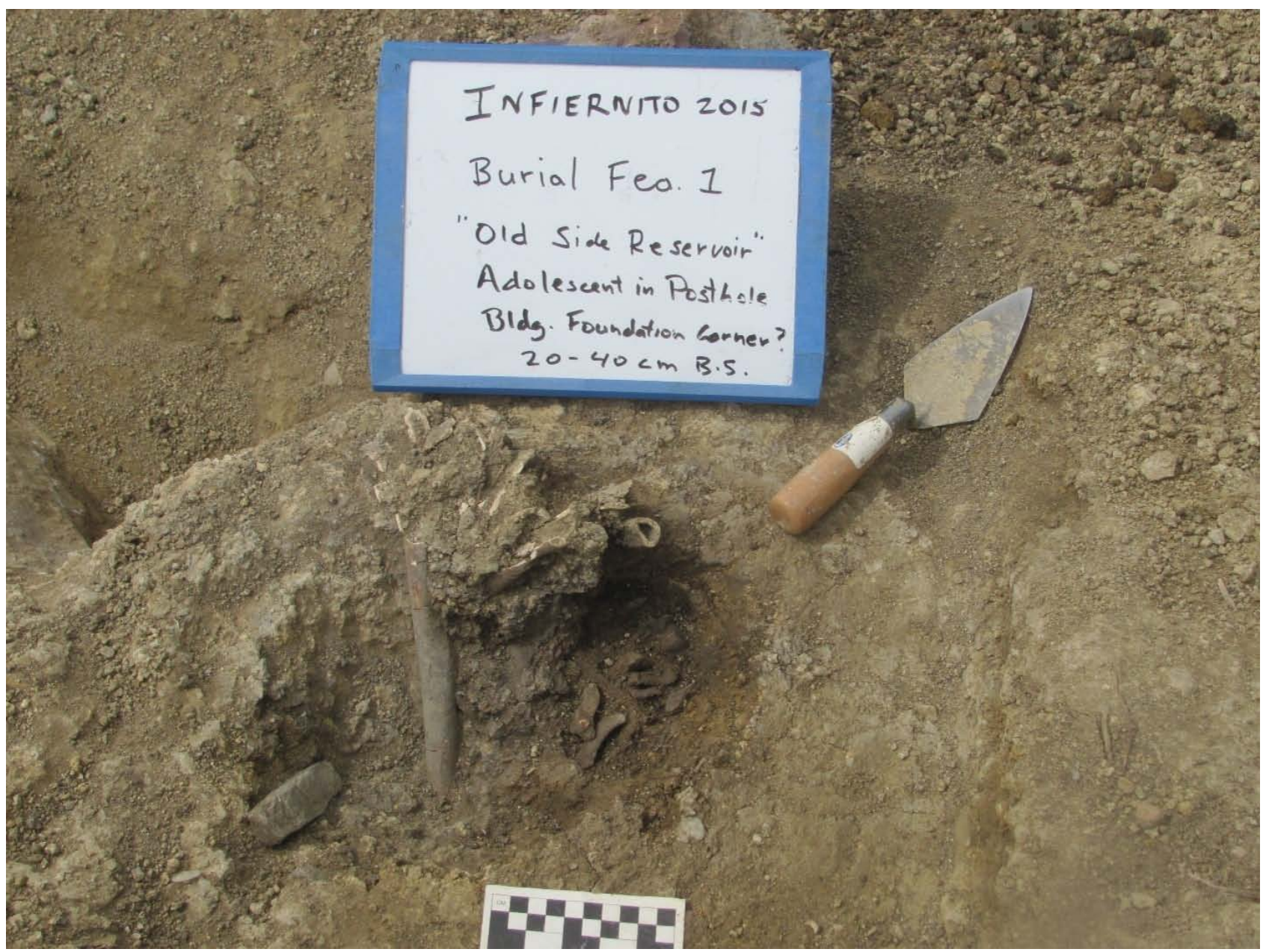

Figure 8. Burial 1 showing a pre-Hispanic pre-adolescent in a tight seated position within a large posthole feature, exposed by recent tractor grading, consistent with Muisca ritual dedicatory sacrifices.

Exposure of Burial 1 also revealed stone fill and a yellow-colored clay (mortar?) a few meters west and parallel to a N-S running stream channel. These contextual data suggest that Burial 1 was interred inside a large posthole $30 \mathrm{~cm}$ in diameter at the base of an architectural feature like a palisade wall. The soil matrix and long bones were stained dark red apparently from a dyed cloth garment and/or a red-colored sap from the wood post; both cotton fibers and hardwood splinters from the native tree Guayacán (Handroanthus chrysanthus) were recovered. The forensic evidence clearly showed a pre-adolescent individual whose partially mutilated skeleton was interred in a large posthole in a tight seated position crushed beneath a large upright post. The broken condition and anatomical positions of the bone indicate a violent sacrifice. Spanish chroniclers in the $16^{\text {th }}$ century reported a ghastly Muisca ritual describing young girls interred beneath large upright posts as dedicatory sacrifices for a new house or temple of an important chief (Simón, 1625, p. 299; Restrepo, 1972, pp. 74-75). Cotton fibers from the burial suggest that the victim was well-dressed and wrapped in a cloth cloak or fine mantel while the general lack of burial interments support a ritual sacrifice. 


\section{Stone Structure 2016}

Operations resumed at the Stone Structure. At this time, three additional human burials were discovered below surface near Burial 1 (Figure 9) including a vessel offering containing bones of an infant (see Burial 4 below). Two of the burials (Burials 2 and 3) were associated with an alignment of stones and mass of yellow clay "mezcla" like Burial 1. Burial 2, $1 \mathrm{~m}$ west of Burial 1, was a small individual seated in a tight upright position with a ground stone artifact, the cranium and most visible bone was crushed suggesting another posthole sacrifice. Burial 3, $2 \mathrm{~m}$ west, was also in a tight seated position possibly associated with a posthole - the top of cranium was missing though the base of the skull was still intact and in its correct anatomical position between the arms and legs-one long bone (femur) to the north was likely displaced by tractor activity.

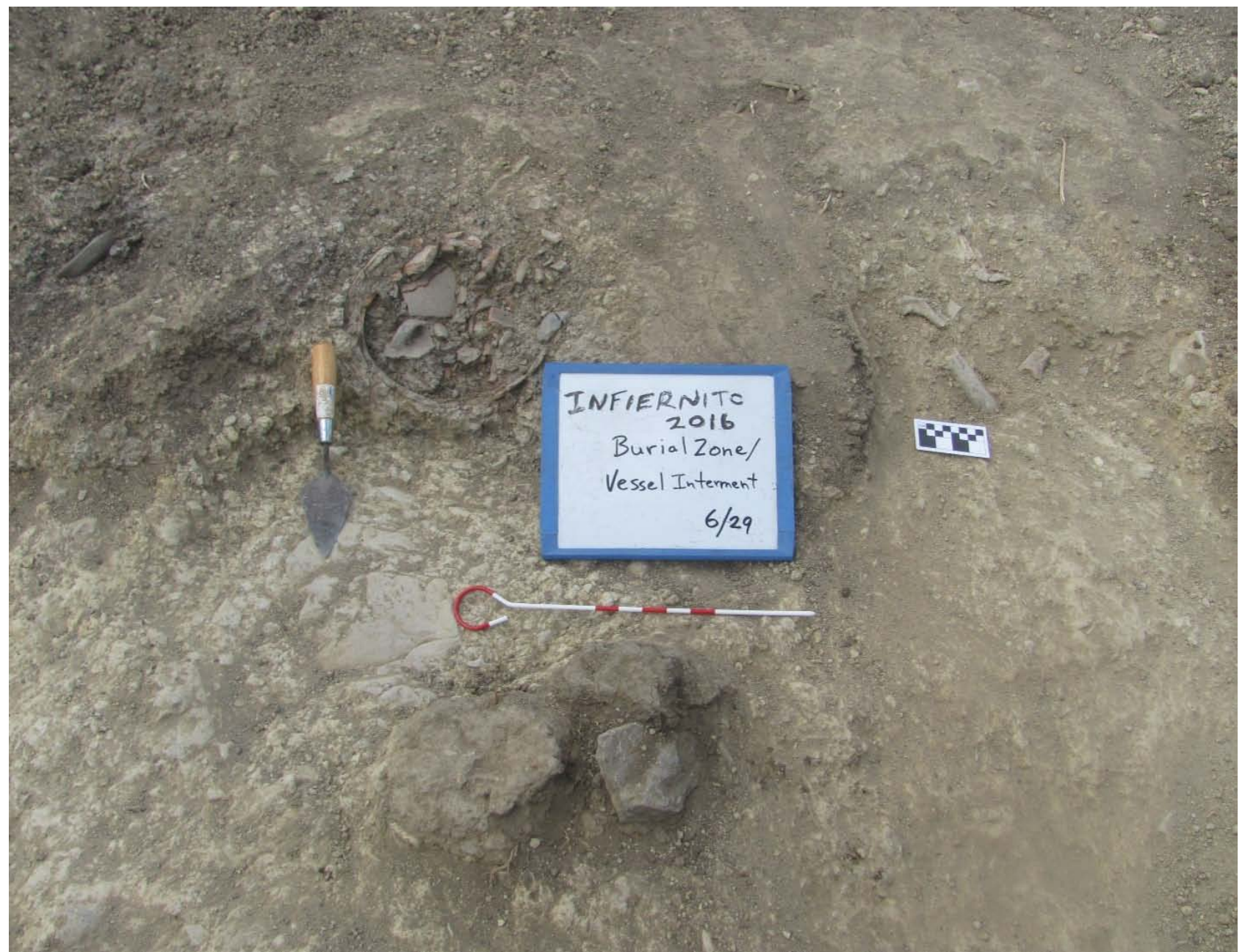

Figure 9. Burials 2-4: Burial 4 (top center) contained two Muisca ceramic vessels and the bones of an infant near an alignment of stones and a mass of yellow clay. Burials 2 and 3, left and right of Burial 4, respectively, were within possible postholes.

Burial 4, between Burials 2 and 3, contained the bones of a neonatal apparently an offering placed between two broken Muisca vessels consisting of one vessel or large body sherd placed atop (inverted?) a handled jar or olla-cuenco vessel (large bowl with incurved rims; Figure10) about $25 \mathrm{~cm}$ in diameter. Unfortunately, the tractor must have sheared off the top of the outer vessel exposing part of the lower jar and the cranium and long bones of a small child flexed in a tight fetal position. A similar child burial between two vessels was reported from the Campo Sagrado del Sur (Silva, 1981, p. 17). The current burials were partially exposed, documented, and reburied for future investigation because there are likely others interred beneath a former palisade wall or building at the eastern entry to a chiefly compound. The associated vessels show paste color and heavy tempering characteristic of Early Muisca wares dated to 1000 and $1200 \mathrm{AD}$. 


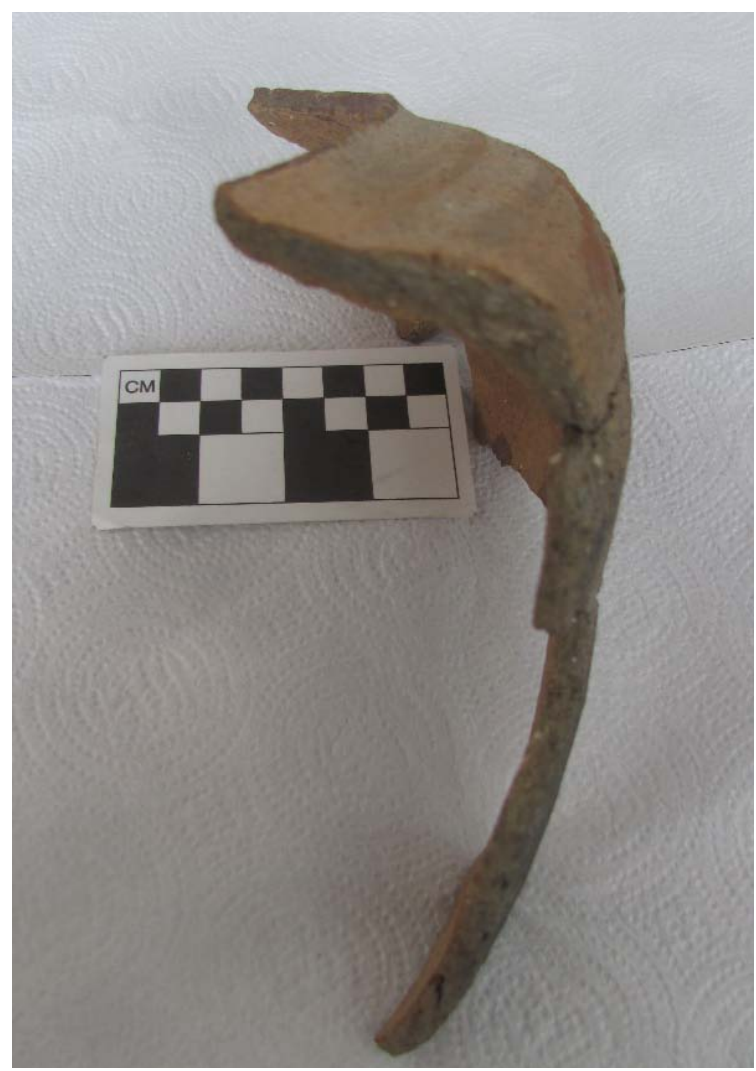

Figure 10. Part of an Early Muisca ware Olla-cuenco vessel from Infiernito like the one found with Burial 4.

At the Stone Structure (Figure 6), a baseline was re-established $10 \mathrm{~m}$ west beginning with Op. 8 to continue subsurface exposures. In the NW, the wall base was heavily damaged by backhoe activity apparently when large stone slabs for the lower walls were forcibly removed. The recovery of 4 stone manos, a rim sherd, and a jar handle outside the wall suggests culinary activities in this context. A stone block and potential wall feature previously exposed in Op. 7 was expanded to reveal other displaced stones of the NW corner (rounded?) and base for the west wall. The sharp contrast between black soil below the stonework and a mottled yellow clay to the south suggest a context outside the main structure and activities that produced midden material on leveled-paved surfaces. Exotic materials including two fine-grained blackstone spindle whorls, three brown stone cobbles, and a piece of calcite crystal were also recovered. Below a packed earthen floor $68 \mathrm{~cm}$ below surface (b.s.), an unusual offering consisting of a freshwater mollusk shell and a hollowed red limestone shaft that may be part of a hook or dart weight for a spear thrower (atlatl).

To the south in Op. 9a white stucco surface was uncovered. Fragments of red roof tiles, historic pottery sherds, and a piece of old glass indicate a more recent floor feature. Later, the landowners confirmed that this space was a corral for cattle and horses more than 100 years ago. Below floor, the same pre-Hispanic tamped earthen surface (Piso I) seen in other units reappeared with another piece of calcite crystal. A probe below floor produced Herrera phase pottery and nearby a large posthole mold (38 cm dia.) was identified as the center post for a perishable roof. Shell, cave stone (stalactite or soda straw), wood fragments, carbon, and a handful of Late Musica potsherds recovered from the central posthole suggest a dedicatory offering in an elite stone structure.

Op. 10 exposed a stone alignment and a base for the west wall (Figure 11). Although many stones were displaced by backhoe activity, a metal horseshoe, horse or cow bone, and jar handles of Ráquira dragged temper-a colonial ware still produced in the valley—confirm that the structure was reused as a historic corral. These intrusive materials were all above the pre-Hispanic occupation surface (Piso I) below which were Muisca ceramics, groundstone manos, a hammerstone, and the most chipped stone lithics found in any unit. A potential hearth outside the west wall contained burned rock and super-heated soil but little ash and midden material typical of cooking activity. Such a hearth may have been cleaned after its last use or functioned for illumination and/or ceremonial fires rather than food preparation per se. A yellow clay outside the west wall and an orange lens of similar material at about $60 \mathrm{~cm}$ b.s. visible in the unit wall suggest a prepared surface below with an elevated stone alignment first revealed in Op. 7. 


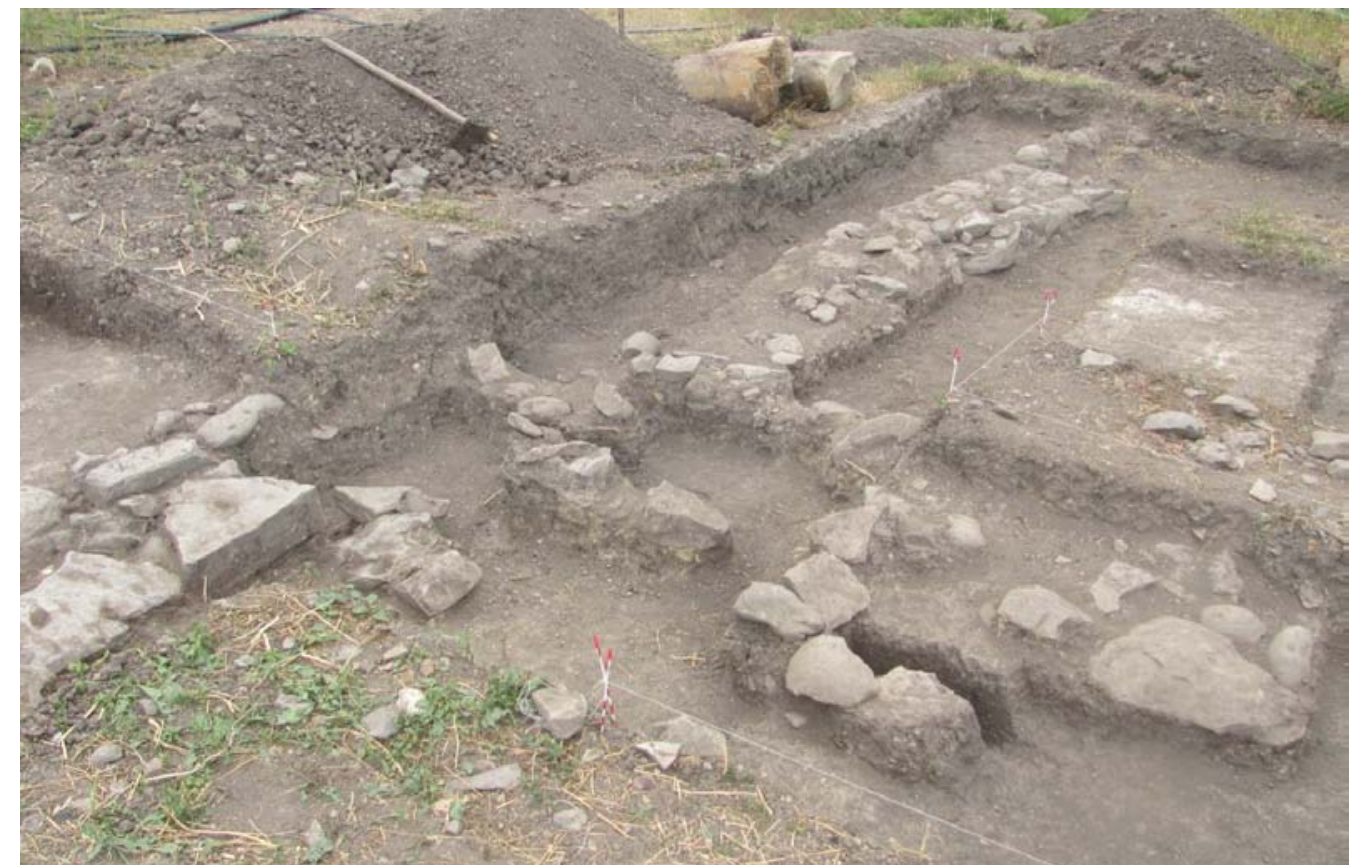

Figure 11. NE view of Operations 8-11 showing the north masonry wall base, the remains of a west wall and hearth feature (below right), various floor surfaces, and stone steps (left) for a raised walkway.

\section{Raised Walkway}

Op. 11 extended Op. 7 north to identify the purpose of an elevated stone alignment (Figure 12). Two polished stone celts, one within the stone wall and another nearby appear to be dedicatory offerings suggesting an important ceremonial space. A $1 \mathrm{~m} \mathrm{x} 2 \mathrm{~m}$ west extension exposed more of the stone alignment showing a two-step stair of shaped and faced stones leading to a higher surface level of tamped yellow clay also seen in other units to the south. This raised floor composed of a fired clay and lime marl surface yielded six wood charcoal samples; a deer mandible, a stone ball or shot, and 2 potsherds as potential on-floor offerings.

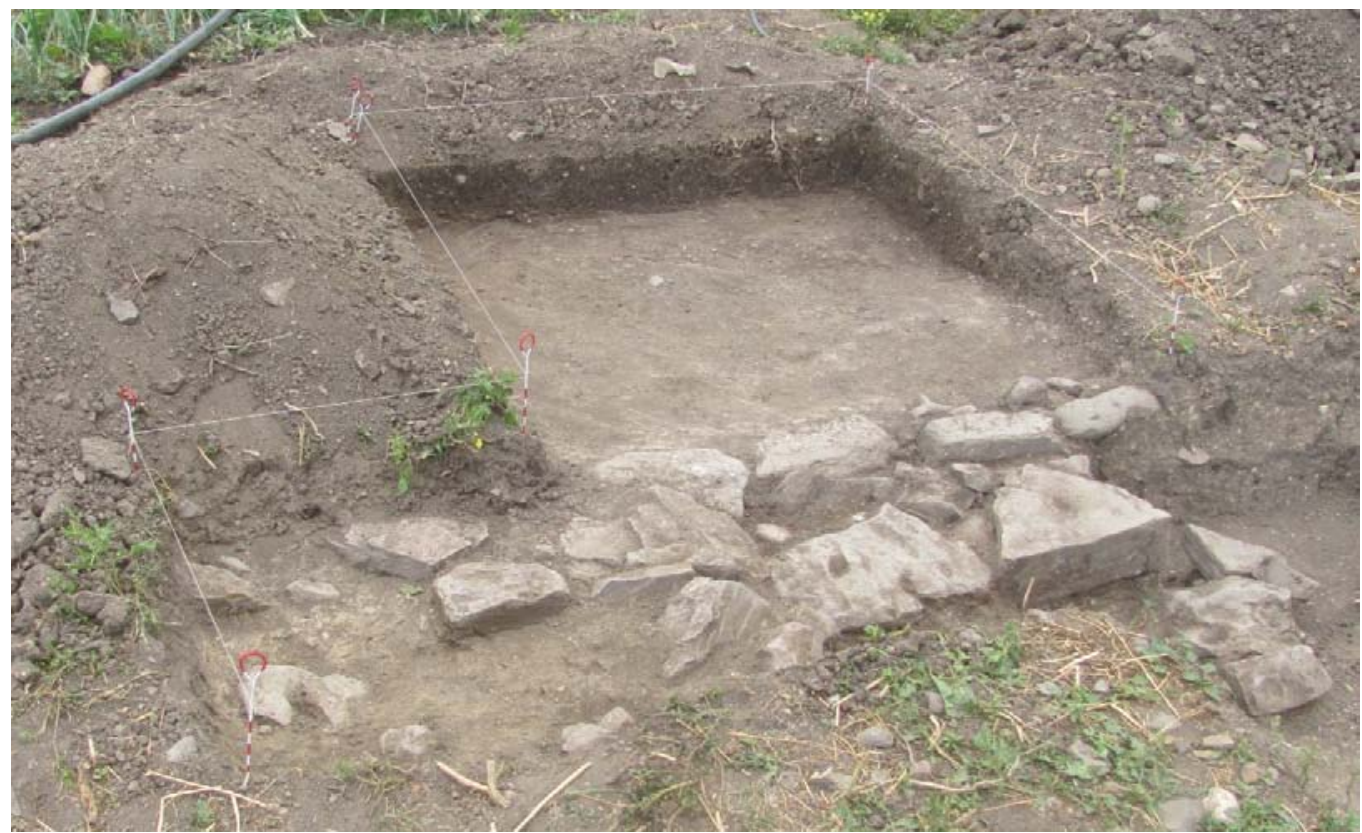

Figure 12. Raised walkway or camillón (Op. 11 and extension) looking north showing a step of shaped and faced stonework and a prepared surface of fired clay aligned with the Dolménica tomb. 
Evidence suggests that this linear stone feature was a "camillón," or raised walkway associated with Muisca chiefly compounds giving access to important buildings and spaces along cardinal directions like the ones reconstructed based on the $16^{\text {th }}$ century Sun Temple at Suamox (Silva Celis, 1945; Herrera \& Cárdale, 2000). This walkway, due south of the Dolménica tomb, raises the question of walkways oriented to other cardinal directions in a cruciform arrangement centered on a temple building; demonstrating this would require extensive excavation and/or geophysical survey, however. Op. 11 indicates that the camillón was $2.2 \mathrm{~m}$ wide, the same width as the reconstructed walkways at Suamox based on the remains of original temple burned down by the Spanish in 1537. With a confirmed length of at least $4 \mathrm{~m}$, its full northern extent is not known, but it is reasonable to infer that it reached El Infiernito since there are no known intervening structures. In fact, the geographic center of the phallic columns, the Dolménica tomb, is $96 \mathrm{~m} \sim 2^{\circ}$ west of true north aligned with the tomb's entryway made up of two parallel N-S rows of 4 columns spaced $1.5 \mathrm{~m}$ apart (Figure $3 \mathrm{~b})$. The tomb is also about the same distance and orientation ( $3^{\circ}$ north of east) from Burials 1-4 described above. This mortuary context of dedicatory internments—sacrifices potentially marks a palisade wall and eastern entrance into Infiernito. Clearly, the Dolménica tomb was a central place potential location of a former Muisca temple with four converging walkways like those at the Sun Temple of Suamox (Moncada, 1979, pp. 5-6).

In sum, the stone alignment served as a step-up to a raised linear platform surfaced with fired yellow-clay forming a raised walkway (camillón) leading to Infiernito. Importantly, these data also imply the likelihood of E, W, and N walkways centered on the Dolménica tomb with an overlying temple building, a focal point for a major religious center of the Muisca by the $13^{\text {th }}$ century AD if not earlier. At least four eastern burials co-occur with the remains of a palisaded compound which possibly surrounded all the stone monuments at El Infiernito including the monolithic stone structure south of the park.

Op. 12, a $1 \mathrm{~m} \times 1.5 \mathrm{~m}$ test unit south of Ops. 9 and 10 between Ops. 5 and 6, yielded a total of six postholes molds for a perishable roof on the southside of the stone structure (Figure 6). No visible stonework or tamped earthen floors were located apparently because backhoe activity and subsequent plowing removed all structural traces (see below). Further evidence of perimeter postholes leaves little doubt that the main structure was conical or oval-shaped. A lower course of large dolomite stones supporting perishable upper walls is virtually certain given the numerous slabs and boulders now piled nearby. What is not certain, however, is if the stone base so clear on the north side and damaged on the west extended around the entire perimeter. Backhoe activity has left no signs of footing stones on the south side and only indirect evidence of boulder door jambs on the SE. Also, just east of Ops. 2 and 3, the recent construction of a brick pedestal for a power meter and erection of a cement electric pole undoubtedly contributed to the missing stone base in this area.

The removal of the building's boulders and related stonework produced a $10 \mathrm{~m} \times 5 \mathrm{~m}$ pile of dolomite megaliths and stone debris with little contextual integrity (Figure 4). Numerous slabs, columns, shaped boulders, flagstones, and large volume of stone debris clearly demonstrate a substantial masonry structure; an entire section (south side?) of the footing base with its original mortar were essentially scooped up and set down virtually intact. A lithic flint core and percussion flakes attached to a marine fossil and pre-Hispanic ceramic sherds were scattered throughout the stone pile. In addition, four carved phallus columns, four rounded and squared pillars with socketed ends reported as part of the SE entrance, two door jambs, and other structural stones demonstrate a building constructed in the same masonry style as many of the stone monuments at El Infiernito.

Two boulder jambs with the same basal dimensions as on-floor impressions were moved back to the building entrance. Four phallic columns, originally on the north side of the stone structure, were also returned. Three of these phallic columns are relatively short ( $\sim \mathrm{m}$ tall) with flattened bases allowing them to stand upright without burial. These data suggest that such symbolically-charged monuments were portable and impermanently displayed suggesting they were used in movable feasts or other periodic community-related ceremonies sponsored by local chiefs at different times and places (see Langebaek, 2005; Salge, 2007).

\section{Infiernito Site Survey}

A regional survey of the Leiva Valley led by archaeologist Carl Langebaek (2001, p. 12; 2005) basically consisted of surface collections and shovel-testing at 100-m intervals but included no specific published data on local sampling at Infiernito and its immediate environs. A synthesis of regional settlement patterns and ceramic associations by period, however, show substantial human settlement from Herrera to Early Colonial times. Indeed, in the Early Musica period 50 percent of the valley's population resided near Infiernito. In a follow-up study, Manuel Salge (2007) conducted systematic survey around the archaeological park performing shovel-tests at 9 different sectors (Figure 
13a). Herrera to Late Muisca occupations were reconstructed based on contour density plots of ceramic frequency. Of particular interest is Sector 4 (Figure 13b), just south of El Infiernito where the stone structure was located, containing 175 shovel samples $(40 \mathrm{~cm}$ x $40 \mathrm{~cm}$ y $40 \mathrm{~cm}$ ) spaced at $5 \mathrm{~m}$ intervals covering $110 \mathrm{~m} \mathrm{E}-\mathrm{W}$ by $40 \mathrm{~m} \mathrm{~N}-\mathrm{S}$ or 0.44 ha. In all, 3,457 ceramic sherds (and 25 fragments of bone) were recovered of which $48 \%$ were classified as pre-Hispanic. These data show that this sector was densely occupied during all Muisca time periods and contained the most foreign ceramic wares identified for the entire study area. Further, three housesites were projected from ceramic refuse patterns dating from Herrera to Late Muisca times (Salge, 2007, pp. 43-45). It is strange, however, that there is no mention of the stone structure in or near Sector 4 even though the boulder walls for this building were largely in situ at that time. Appearing as a heavily vegetated oval feature on Google Earth satellite imagery taken in March of 2006, the boulders are clearly visible in their current relocation on the 2010 imagery, thus confirming informant accounts.

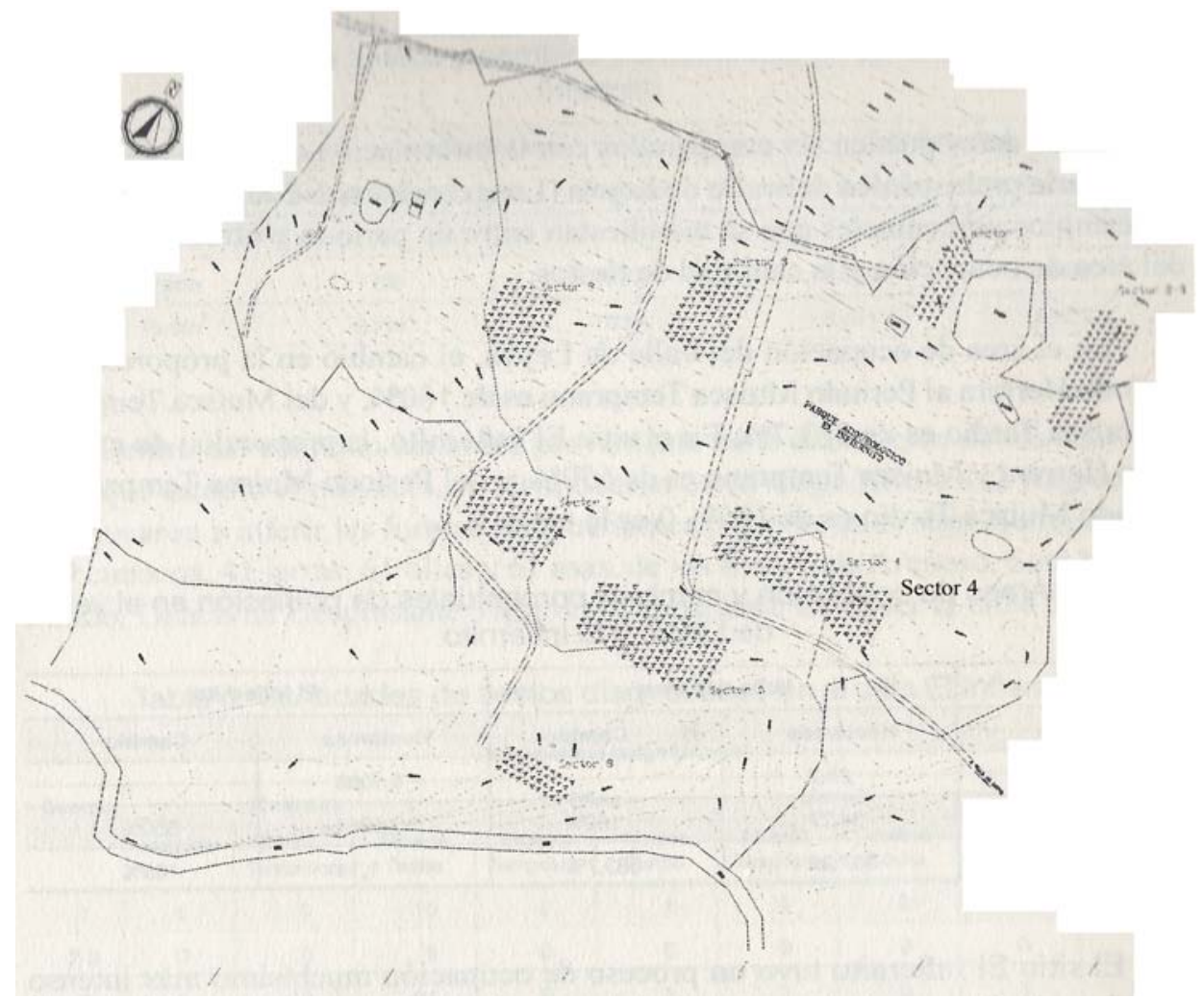

Figure 13a. Plan map showing the locations of shovel testing excavation sectors in and around El Infiernito performed by Manuel Salge Ferro (2007, p. 31). Sector 4 is the area of the Stone Structure. The dashed markings appear to be contour coordinates.

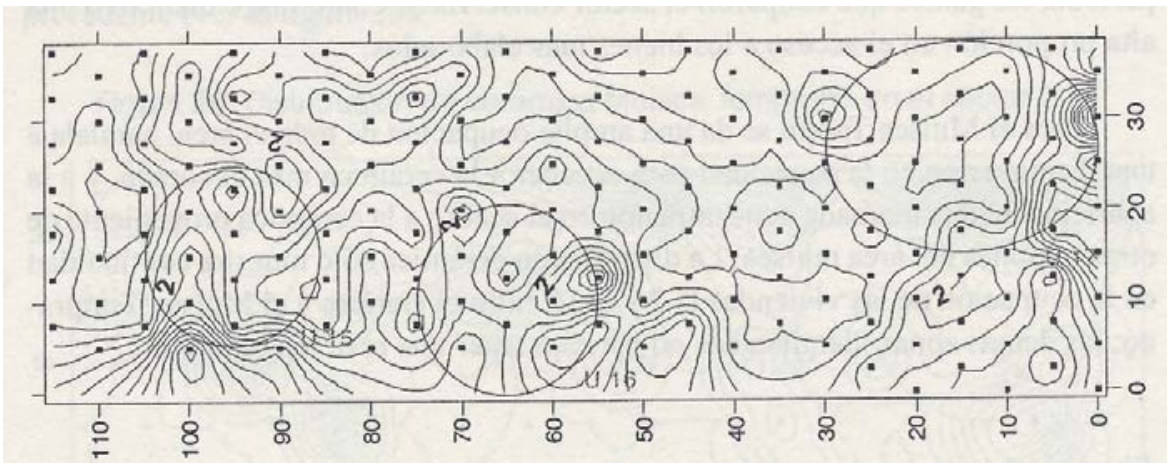

Figure 13b. Contour density plots of ceramic sherd frequency at Sector 4 showing projections of Late Muisca period houses (uta) at El Infiernito (Salge, 2007, p. 45). 
Reconnaissance around El Infiernito contributed new archaeological evidence for intensive agriculture and water management (Smyth et al., 2016). Hydraulic works were identified along with evidence for major erosion events potentially related to rapid climate change, i.e., significant droughts and/or major flooding episodes. The Loma la Cabrera just north of El Infiernito is an upland area where a natural perennial spring (Cañada las Peñas) situated above a carboniferous shale deposit produces hydrostatic surface water that drains into the Rio Leyva. Below the spring are two possible anthropogenic ovoid pools reminiscent of the ceremonial baths or "lavapatas" at the Alta Magdalena site of San Agustín in southern Huila (Duque Gómez, 1964; Drennan, 1995). A parallel drainage shows a stone catchment surface and conduit connected to a double alignment of huge upright megalithic boulders now partially displaced above a cross-channel boulder wall (Figure 14). These hydraulic features were clearly engineered as a holding tank reservoir and check dam for a gravity feed system designed to collect and divert seasonal rainwater to nearby agricultural fields along the Rio Leyva alluvium adjacent to the Infiernito Observatory.

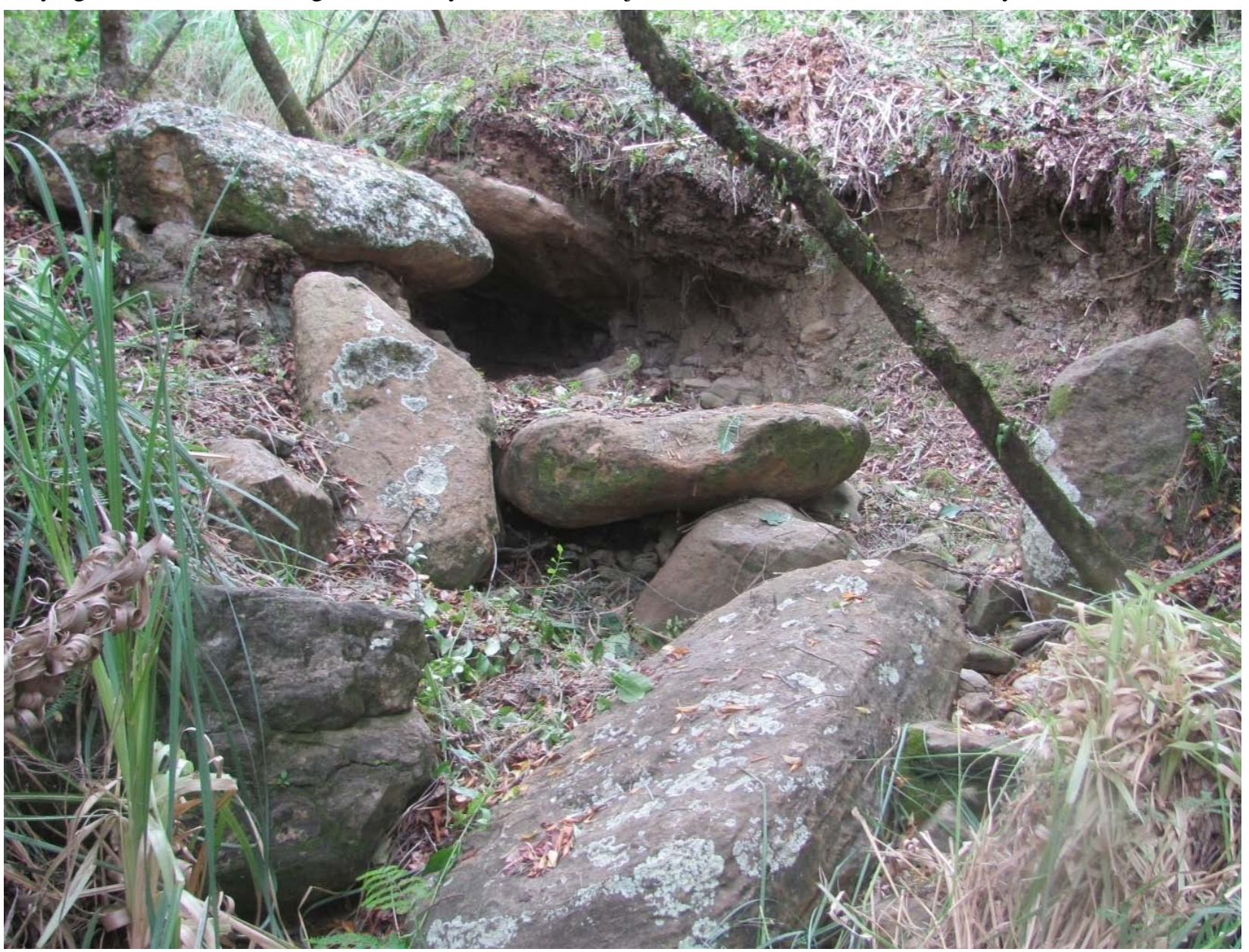

Figure 14. Photo of a potential hydraulic feature looking northeast showing shaped upright megalithic boulders now partially displaced that served as walls for a reservoir above a check dam and downstream from a catchment zone and linear drain conduit. The boulder at the bottom is about $2 \mathrm{~m}$ long.

Trenching along the Rio Leyva floodplain revealed a current topsoil with little soil development, but a lower topsoil buried by $175 \mathrm{~cm}$ of deposition and greater soil development (Figure 15) suggesting major past erosion and flooding events. Deeper cores indicated similar lower sequences, and evidence of more than one such cycle of erosion (Beach et al., 2013; Smyth et al., 2016; Wells et al., 2015). To combat flooding the Muisca must have built raised fields along river alluvium like those documented along the Rio Bogotá near the town of Funzá and elsewhere on the Sabana de Bogotá. Early Colonial sources from the Valley of Zaquenzipá (Leiva) clearly indicate that the Muisca practiced raised-field agriculture and canal irrigation long before European Contact, and that pre-Hispanic hydraulic features were still being used by Spanish Contact (Restrepo, 1972; Mora, 2011; Mora, 2012; Mora, 2015; Boada 2017). 


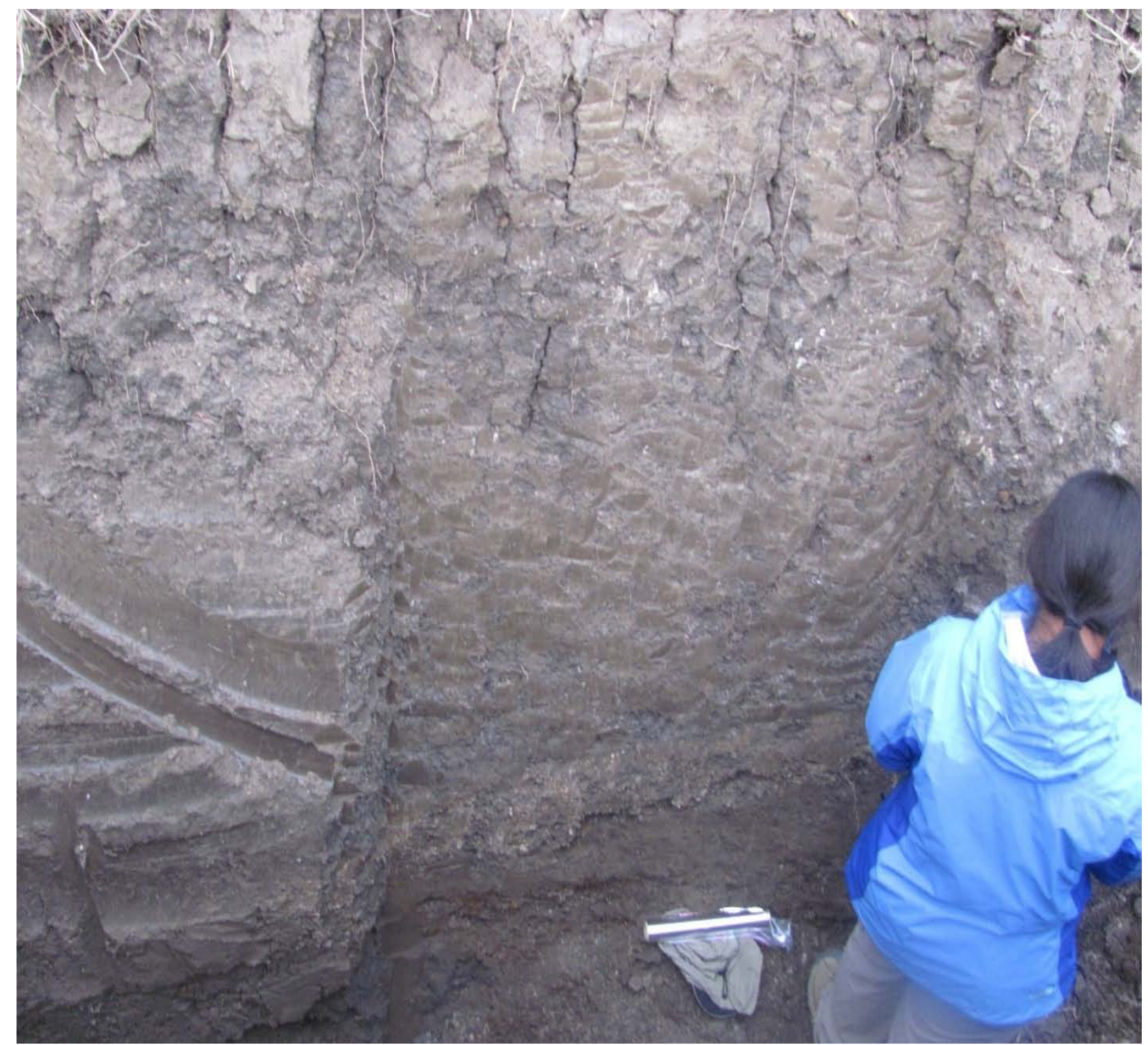

Figure 15. Soil stratigraphy at Trench 1 showing evidence (lower center above scale) for stream channels below an immature current topsoil between the Loma la Cabrera and Rio Leyva.

In 2017 survey along a dirt road and former olive orchard west of the archaeological park revealed a stone-lined channel bordered by Guayacán trees (Figure16a). This potential ancient canal is nearly $2 \mathrm{~m}$ deep and begins at the base of the Loma la Cabrera running some $500 \mathrm{~m}$ south into the alluvial fields along the Rio Leyva. An irrigation feature here is consistent with other hydraulic features and stream channels identified on the other side of El Infiernito.

Importantly, near the canal are five enormous dolomite monoliths up to $3 \mathrm{~m}$ long and $1.5 \mathrm{~m}$ wide (Figure 16b). According to local informants, these massive, shaped boulders were originally found $12 \mathrm{~m}$ east but moved by heavy machinery to their present location bordering a farm road. Colombian air photos (C-2801) of the Leiva Valley taken between 2001 and 2006 by the Instituto Geográfico Agustín Codazzi and Google Earth images in 2006 appear to confirm informant accounts of the monolith's original location. Given the enormous weight of these massive stones $\left(2,899 \mathrm{~kg} / \mathrm{m}^{3}\right)$, without modern machinery, they were unlikely moved until recently. In their original context, these five monoliths align precisely to $248^{\circ} \mathrm{W}$ of the observatory's former central $5 \mathrm{~m}$ tall upright column, five days after the Summer Solstice (June 21) that once functioned as a firmament to measure the height of the sun and other celestial movements (Silva, 1981). 


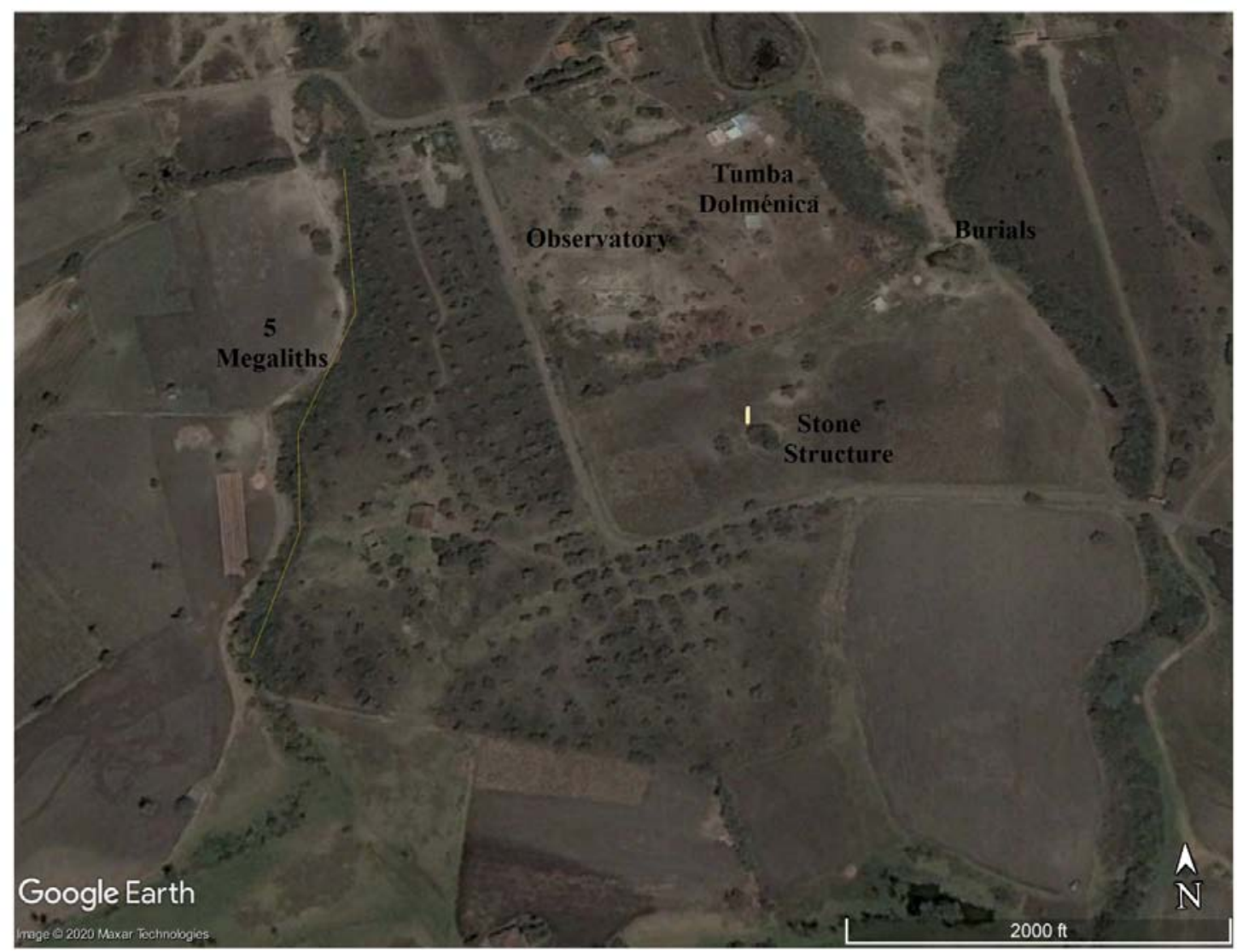

Figure 16a. Google Earth satellite image (2006) showing El Infiernito and environs, including the stone structure and walkway, the Dolménica Tomb and east burials along a stream channel, and the locations of a western canal (yellow line) and 5 megaliths aligned with the center of the observatory when a quintuple planetary grouping was visible on $710 \mathrm{AD}$.

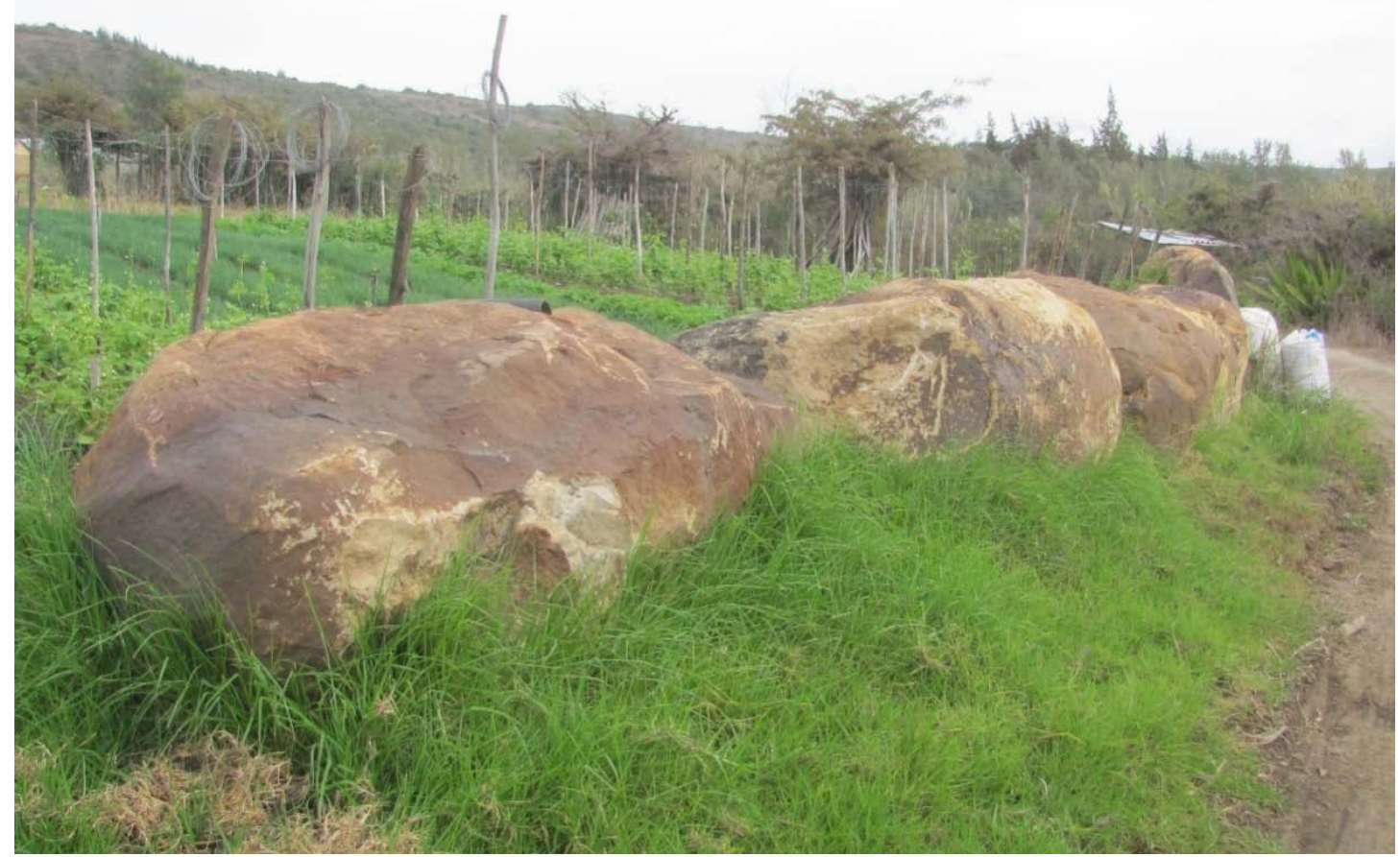

Figure 16b. Five massive megaliths along the western canal aligned with center of the astronomical observatory perhaps representing a rare quintuple planetary grouping visible in $710 \mathrm{AD}$. 
Astrophysicists has long maintained that rare celestial phenomena visible to the naked eye like multiple planetary groupings, inspired ancient cultures to select auspicious times for rites, seasonal activities, and forecasting events (de Meis \& Meeus, 1994). On the evening of June 26, 710 AD, a quintuple planetary grouping (Mercury, Venus, Mars, Jupiter, and Saturn) became visible after sunset along a heading of $248^{\circ}$ with a separation of $<6^{\circ}$ (Figure 17), the diameter inscribing the planets (de Meis \& Meeus, 1994, p. 294). This quintuple planetary grouping would have been observable to stargazers at El Infiernito. If the five massive boulders represent five conjoined planets, a celestial spectacle aligned with the 5-m tall column marking the sun's path, these monoliths could indicate where these planets first appeared over the site and night sky in $710 \mathrm{AD}$, thus commemorating a date of momentous cultural or historical significance at El Infiernito. This date, importantly, corresponds closely to current thinking regarding the first Herrera farming communities in the Leiva Valley (Langebaek et al., 2001). Whether the Herrera phase was a separate culture or a nearly phase of the Muisca remains unclear, but their ceramics are quite distinct (Salamanca, 2000). Late June also begins the dry months between dual rainy seasons, the coldest time of the year and critical period for rainfall-based farming.

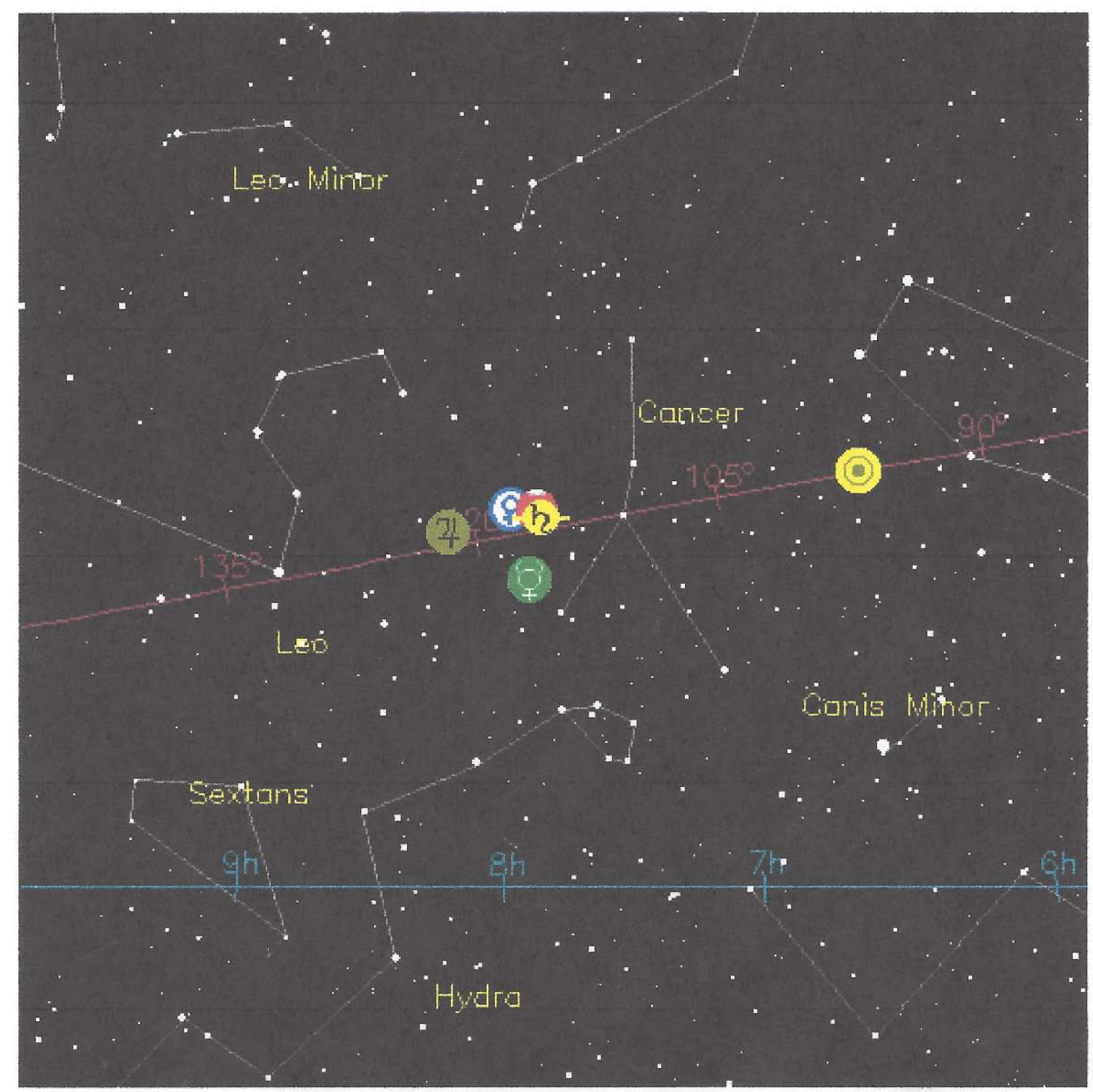

Figure 17. Sky map of a quintuple planetary grouping (Mercury, Venus, Mars, Saturn, and Jupiter) and constellations visible to the naked eye along the sun's path on Thursday, June 26, 710 AD. Aim point: 7h 48m 192 Dec: +1951'6”. (https://fourmilab.ch/cgi-bin?Yourtel?lat+19.8518\&ns=North\&....). 


\section{Conclusions}

Investigation at the site of a unique stone structure near El Infiernito, despite removal of most of its stonework and monoliths, has provided new evidence for a rare masonry building of the ancient Muisca. Results show an elite building with boulder slab walls seated upon a dry stone base that together sustained perishable upper walls and thatched roofing; the latter is typical of Muisca houses ( $u t a$ ) which are round structures constructed of perishable materials with minimal or no stone foundation. While this building was not large $\left(\sim 25 \mathrm{~m}^{2}\right)$ but clearly apsidal or oval-shaped judging from the reconstructed posthole configuration, it was a significant monumental building in an elite compound with multiple structures occupied since Herrera times (Salge, 2007; Smyth et al., 2016). A surprise find was a raised walkway that aligns and likely connects to the Dolménica tomb, a megalithic substructure near the center of El Infiernito. This central place in a forest of phallic columns is argued to have been buried beneath a Muisca temple possibly accessed by four cruciform walkways like those at the Sun Temple of Suamox (Silva, 1945; Monclada, 1979).

East of the Dolménica tomb (and alleged temple) bordering a stream channel, human burials were uncovered with at least one confirmed posthole sacrifice in a mortuary context about the same distance from the tomb as the stone building implying an eastern walkway and formal entrance into a chiefly compound. These data suggest a palisade wall for a large compound incorporating much of El Infiernito including the chiefly residential area south of the ceremonial zone. These preliminary data offer tangible evidence for an elite community directly associated with the solar astronomical observatory.

The astronomical-meteorological observatory, a focal point of tourism and public attention, must be understood in larger regional context. The ancient community, a unique stone building in a chiefly compound, and surrounding environs are key for interpreting the stone monuments. Indeed, it was not until the 1980s that the archaeological establishment recognized any community associated with the observatory. Recent investigations have determined that El Infiernito and a water temple behind Villa de Leyva were spatially related representing integral Muisca settlement features inspired by an observed cosmological relationship between the sun and water in both real and ritual terms (Smyth, 2017; Smyth, 2018). A diagonal of stone columns in the observatory precisely aligns with a water temple on the Winter Solstice that undoubtedly signaled a significant time marking the start of the solar year and renewal of the agricultural cycle (Ingativa, 2012). Born from a sacred mountain (Cerro Santo), holy waters began their western journey on the Rio Leyva to the observatory and beyond; a symbol of fertility and solar power, ultimately harnessed via hydraulic agriculture (raised-fields and canals) follow the setting sun. Stream channels and other irrigation works on both east and west sides of the observatory appear to be part of a larger hydraulic system with potential great antiquity. In addition, five massive boulders or mega-monuments aligned with the observatory's 5 -m central column along the western path of the sun may symbolize a quintuple planetary grouping visible in the night sky on June 26, $710 \mathrm{AD}$, thus commemorating a momentous cultural moment perhaps even the founding of $\mathrm{El}$ Infiernito as well as symbolizing the fragility of agricultural subsistence.

The formation of chiefdoms in the Leiva Valley were strongly conditioned by environmental factors such as dual wet and dry seasons, periodic drought cycles, and rainfall farming that is marginal at best. A multi-method approach demonstrates the importance of studying human-environment interactions namely chiefdom ecodynamics that begin to contribute new evidence for intensive agriculture, water management, and the effects of valley erosion past and present (Mora, 2011). Incorporating stone architecture and settlement landscapes, the built environment as well as hydraulic systems were closely tied to religious cosmology associated with a mountain water temple, celestial events, and the astronomical-meteorological observatory at El Infiernito. To Muisca cosmology, the reality and ideology of water were not separate spheres in that they saw no absolute distinction between the physical and spiritual realms of their world. Therefore, both tangible and intangible responses were necessary to overcome the limitations posed by both the natural and cultural environments. Ecodynamics approaches in this regard consider the full-range of human adaptive abilities in terms of how intermediate-level chiefdom societies overcame climate-related environmental constraints, a question that demands greater attention in the archaeology of the Eastern Andean highlands.

\section{Acknowledgments}

This research was funded by a grant from the National Geographic-Waitt Foundation (W352-14), contributions to the Foundation for Americas Research, Inc., and support from the University of Texas at Austin. I would like to thank the Awazako Family for their assistance in beginning this preliminary project. I greatly appreciate the expertise and valuable services of Timothy Beach, Eric Weaver, Luisa Aebersold, Greta Wells, Beth Cortwright, Nikki Woodward, 
Pedro Luis Suárez, Pilar Suárez Smyth, and Martha Esperanza Suárez. Also, the people of the beautiful Leiva Valley and City of Villa de Leyva, especially the Palacio Vargas family of the Hospederia Villa Palva, were most helpful and cordial in making our time there memorable and enjoyable.

\section{References}

Acosta, Joaquin. (1850). Carta escrita a J. Jomard (Letter written to J. Jomard). www.lablaa.org/blaavirtual/ letrab/bio/bio45.htm.

Ancízar, M. (1983). Peregrinación de Alpha. Por las provincias del norte de la Nueva Granada, en 1850-51 (The Pilgrimage of Alpha in the Northern Provinces of New Granada, 1850-51). Editorial Incunables, Bogotá, Colombia [1851].

Beach, Timothy., Luzzadder-Beach, Sheryl, and Lohse, Jon. (2013). Landscape Formation and Agriculture in the Wetlands of Northwestern Belize. In Jon C. Lohse, ed., Classic Maya Political Ecology. UCLA Cotsen Institute of Archaeology Press, Los Angeles, pp. 43-67. ISBN 978-1-931745-70-3.

Beach, Timothy, S. (2015). Keynote on Soil and Sediment Transfers in Middle America at the PAGES working group on Global Soil and Sediment Transfers in the Anthropocene (GloSS) at the Department of Geography, University of Bonn, Germany, $19^{\text {th }}-21$ st August.

Boada Rivas, Ana María. (1998). Bases of Social Hierarchy in the Muisca Central Village of the Northeastern Highlands of Colombia. Universityof Pittsburgh, Pittsburgh.

Boada Rivas, Ana María. (2000). Variabilidad mortuoria y organización social muisca en la sabana de Bogotá. En Sociedades complejas de la sabana de Bogotá, siglos VII al XVI d. C., Mortuary variability and Muisca social organización of the Savanna of Bogota, B. Enciso, M. Therrien eds. Instituto Colombiano de Antropología e Historia, Colombian Institute of Anthropology and History (ICANH): Bogotá, Colombia.

Boada Rivas, Ana María. (2006). Patrones de asentamiento regional y sistemas de agricultura intensiva en Cota y Suba, Sabana de Bogotá, (Colombia), Regional settlement patterns and systems of intensive agriculture in Cota and Suba, Savanna of Bogotá. FIAN, Banco de la Republica, Bank of the Republic, Bogotá.

Boada Rivas, Ana María. (2007). The Evolution of Social Hierarchy in a Muisca Chiefdom of the Northern Andes of Colombia. University of Pittsburgh Memoirs in Latin American Archaeology No. 17, Pittsburgh. ISBN 987-1-877812-83-5.

Botiva, Alvaro. (1989). La altiplanicie cundiboyacense. En Colombia prehispánica regiones arqueológicas, The Cundiboyacense highplataeu. In Prehispanic archaeological regions of Colombia. ICANH: Bogotá, Colombia, pp. 77-116.

Broadbent, Sylvia. (1968). A Prehistoric Field System in Chibcha Territory, Colombia. Ñawpa Pacha 6:135-147.

de Meis, Salvo and Meeus, Jean. (1994). Quintuple planetary groupings_-Rarity, historical events, and popular beliefs. Journal of the British Astronomical Association 104: 6.

Drennan, Robert. (1995). Mortuary Practices in the Alto Magdalena: the Social Content of the San Augustin Culture. In Tombs for the Living: Andean Mortuary Practices, T. Dillehay, ed. Dumbarton Oaks Research Library and Collection, Washington, D.C. Pp. 79-110. ISBN-10: 0884023745

Duque Gómez, Luis. (1964). Exploraciones Arqueológicas en San Augustin. Archaeological Explorations at San Augustin. Revista Colombiano de Antropología, Suplemento No. 1, Instituto Colombiano de Antropología, Imprenta Nacional, Bogotá, Colombia.

Falchetti, Ana Maria. (1975). Arqueología de Sutamarchán. Archaeology of Sutamarchan. Biblioteca Banco Popular, Popular Bank Library, Bogotá, Colombia.

Henderson, Hope. and Ostler, Nicholas. (2005). Muisca Settlement Organization and Chiefly Authority at Suta, Valle de Leyva, Colombia: A Critical Appraisal of Native Concepts of House for Studies of Complex Societies. Journal of Anthropological Archeology 24(2): 148-178. ISSN: 0278-4165.

Herrera, Leonor and Cárdale, Marianne. (2000). Caminos Precolombinos: Las Vías, los Ingenieros y los Viajeros. Precolombian Roads: The Vias, the Engineers, and Travelers. ICANH: Instituto Colombiano de Antropología e Historia, Bogotá.

Https://fourmilab.ch/cgi-bin?Yourtel?lat+19.8518\&ns=North\&.... 
Ingativa Nuesa, Xieguazinsa. (2012). Resignación Cosmogónica Muisca Chibcha en el Valle de Zaquenzipá. En Villa de Leyva Historia y Legado, Bicentenario de la Consolidación del Congreso Nacional, Cosmogonic Resignation of the Chibcha Muisca in the Zaquenzipá Valley. In Villa de Leyva History and Legend, editado por E. Reyes M., V. Arenas V., eds. Villa de Leyva, Boyacá, Colombia, pp. 137-159.

Kruschek, Michael. (2003). The Evolution of the Bogota Chiefdom: A Household View. University of Pittsburgh, Pittsburgh.

Langebaek, Carl H. (1995). Regional Archaeology in the Muisca Territory: A Study of the Fúquene and Susa Valleys. Memoirs in the Latin American Archaeology No. 9, University of Pittsburgh, Universidad de los Andes. Pittsburgh. ISBN 1-877812-34-X.

Langebaek, Carl H. (2001). Arqueología regional en el Valle de Leiva: Procesos de ocupación humana en una región de los Andes Orientales de Colombia. Colección Informes Antropológicos, Regional archaeology in the Valley of Leiva: Processes of human occupation in a region of the Eastern Andes of Colombia. Anthropological Reports Collection, ICANH: Bogotá, Colómbia. ISBN 958-97054-2-1.

Langebaek, Carl H. (2005). Fiestas y Caciques Muiscas en el Infiernito, Colombia: Un Análisis de la Relación entre Festejos y Organización Política. Fiestas and Muisca Chiefdoms at El Infiernito, Colombia: Analysis of the Relationship between Festivals and Political Organization, Boletín de Arqueología, Archaeology Bulletin PUCP 9: 281-295. ISSN 1029-2004.

Langebaek, Carl H. (2013). Words, Things, and Text: El Infiernito, Archaeology, Documents and Ethnology in the Study of Muisca Society. In Against Typological Tyranny in Archaeology: A South American Perspective. ISBN 10:1461487234.

Moncada, Jaime. (1979). Informe comisión: Vereda de Monquirá sitio El Infiernito, Boyacá. Commision Report: Village of Monquirá El Infiernito Site, Boyacá. ICANH: Bogotá, Colombia.

Mora Pacheco, Katherinne Giselle. (2011). Prácticas Agrícolas Coloniales y Degradación del Suelo: El Caso de Saquencipá. Colonial Agricultural Practices and Degradation of Soils: The Case of Saquencipá. Revistaeográfica de América Central, Numero Especial, Geographic Review of Central America, Special Issue, EGAL 1-14.

Mora Pacheco, Katherinne Giselle. (2012). Livestock Farming in the Saquencipá Valley, New Kingdom of Granada, Colombia in the 16th and 17th Centuries. Pastos 42(2): 251-272.

Mora Pacheco, Katherinne Giselle. (2015). Prácticas agropecuarias coloniales y degradación del suelo en el Valle de Saquencipá, Provincia de Tunja, siglos XVI y XVII. Colonial Agricultural Practices and Degradation of Soils: The Case of Saquencipá, Province of Tunja, XVI and XVII Centuries. Bogotá: Universidad Nacional de Colombia, National University of Colombia.

Morales, Juan David. (2009). Archaeoastronomy in the Muisca Territory. Cosmology Across Cultures. ASP Conference Series 409: 272-276.

Reichel-Dolmatoff, Gerardo. (1982). Astronomical Models of Social Behavior Among Some Indians of Colombia. Annals of the New York Academy of Sciences 385: 165-181.

Restrepo, Vicente. (1972). Los chibchas antes de los conquista española-Atlas y Anexo arqueológicos, Biblioteca Banco Popular: The Chibchas before Spanish Conquest-Archaeological Atlas and Anexo of the Popular Bank Library: Bogotá, Colombia. [1895]

Salamanca, María Fernanda. (2000). Asentamientos tempranos en el valle de Sáchica, Boyacá. Tesis de grado. Early Settlements in the Valley of Sáchica, Boyacá. Graduate Thesis. Universidad de los Andes, University of the Andes: Bogotá, Colombia.

Sáenz, Napoleón Ignacio. (1968). Villa de Leiva: tradiciones y anhelos. Litografía Ayudantía General Comando del Ejército, Villa de Leiva: traditions and desires. Lithograph Adjutancy of the Commanding General of the Army. Bogotá, Colombia.

Salge Ferro, Manuel. (2007). Festejos Muiscas en el Infiernito, Valle de Leyva: La consolidación del Poder Social. Muisca Festivals at El Infiernito, Valley of Leyva: The Consolidation of Social Power. University of the Andes, Bogotá, Colombia. ISBN 978-958-695-287-3.

Silva Celis, Eliécer. (1945). Excavaciones Arqueológicas en Sogamoso. Archaeological Excavations in Sogamosa. En Boletín de Arqueología, In Bulletin of Archaeology. Vol. I: 93-112, Bogotá, Colombia.

Silva Celis, Eliécer. (1981). Investigaciones arqueológicas en Villa de Leiva. Archaeological Investigations in Villa de Leyva. En Boletín del Museo del Oro, Año 4, Enero-Abril de 1981, In Bulletinofthe Gold Museum, January-April 
1981. Banco de la República, Bank of the Republic, Bogotá, Colombia.

Silva Celis, Eliécer. (1983). Descubrimientos arqueológicos en Villa de Leiva. Comunicación científica preliminar. En Memorias II Congreso de Antropología en Colombia. Archaeological discoveries in Villa de Leyva. Preliminary scientific communiques. Universidad de Antioquia. Medellín. Tomo 1: 235-250.

Simón, Pedro. (1981). Noticias historiales de las conquistas de Tierra Firme en las Indias occidentales. Historical record of the conquest of lands in the Western Indies. Biblioteca del Banco Popular, Popular Bank Library: Bogotá, Colombia [1627].

Smyth, Michael P. (2017). Chiefdom Ecodynamics and Muisca Cosmology in the Valley of Leiva, Highland Colombia. Global Journals of Social Science-B 17(3): 21-45; DOI:10.15184/aqy.2016.266

Smyth, Michael P. (2018). Hydraulic Chiefdoms in the Eastern Andean Highlands of Colombia. Heritage 1: 100-121. doi:10.3390/heritage10100082018.

Smyth Michael P., Beach. Timothy S., and Weaver, Eric M. (2016). Climate Change and Chiefdom Ecodynamics in the Eastern Andean Cordillera of Colombia. In Changes in Latitudes, Changes in Attitudes: Transitions and Thresholds throughout Central America and Beyond. Occasional Papers, Number 21, the Center for Archaeological and Tropical Studies. Luisa Aebersold, Samantha M. Krause, eds. University of Texas-Austin, pp. 15-32.

Triana, Miguel. (1972). La civilización chibcha. The Chibcha civilization. Talleres Gráficos de Carvajal \& Cía. Cali, Colombia 1972.

Wells, Greta., Aebersold, Luisa., Beach Timothy S., and Smyth, Michael P. (2015). Preliminary soil erosion and sediment budgets in the Valley of Leyva, Boyacá, Colombia. Poster paper in preparation for the Geological Society of America Annual Meeting in Baltimore, MD.

Zerda, Liborío. (1972). El Dorado. Tomo II. Biblioteca Banco Popular, Popular Bank Library: Bogotá, Colombia. [1882]. 